\title{
Review of the History and Current Status of Cell-Transplant Approaches for the Management of Neuropathic Pain
}

\author{
Mary J. Eaton, ${ }^{1}$ Yerko Berrocal, ${ }^{2}$ Stacey Q. Wolfe, ${ }^{3}$ and Eva Widerström-Noga ${ }^{1,4}$ \\ ${ }^{1}$ Miami VA Health System Center, D806C, 1201 NW 16th Street, Miami, FL 33125, USA \\ ${ }^{2}$ Department of Cellular Biology and Pharmacology, Herbert Wertheim College of Medicine, Florida International University, \\ Miami, FL 33199, USA \\ ${ }^{3}$ Department of Neurosurgery, Tripler Army Medical Center, 1 Jarrett White Road, Honolulu, HI 96859, USA \\ ${ }^{4}$ The Miami Project to Cure Paralysis, Miller School of Medicine at the University of Miami, Miami, FL 33136, USA
}

Correspondence should be addressed to Mary J. Eaton, meatonscience@gmail.com

Received 8 March 2012; Accepted 9 April 2012

Academic Editor: Steve McGaraughty

Copyright (c) 2012 Mary J. Eaton et al. This is an open access article distributed under the Creative Commons Attribution License, which permits unrestricted use, distribution, and reproduction in any medium, provided the original work is properly cited.

\begin{abstract}
Treatment of sensory neuropathies, whether inherited or caused by trauma, the progress of diabetes, or other disease states, are among the most difficult problems in modern clinical practice. Cell therapy to release antinociceptive agents near the injured spinal cord would be the logical next step in the development of treatment modalities. But few clinical trials, especially for chronic pain, have tested the transplant of cells or a cell line to treat human disease. The history of the research and development of useful cell-transplant-based approaches offers an understanding of the advantages and problems associated with these technologies, but as an adjuvant or replacement for current pharmacological treatments, cell therapy is a likely near future clinical tool for improved health care.
\end{abstract}

\section{Introduction}

The transplantation of cells into the CNS for therapeutic purposes can be envisioned with increasingly demanding goals in mind: (1) local and sustained provision of therapeutic molecules, such as pharmacologic agents and neurotrophic factors; and (2) replacement of lost cellular populations and reconstruction of local neuronal circuitry. To a large extent, the demands of the particular therapeutic application will be the key factor in determining the goals of the transplant paradigm, and this guides both the selection of optimal cell type(s) and parameters (graft dose, site, timing, immunosuppressive regimen, etc.) for transplantation. With this in mind, the current review will explore the wide variety of approaches in neural transplantation that have been explored for the therapeutic management of pain. Since the goals of pain management can be widely disparate, approaches have evolved along distinctive paths during the progression of this field. Thus, while the provision of a local cellular source of biologic, rather than pharmacologic analgesic molecules may be appropriate in the management of some etiologies of new-developing neuropathic pain, cases of chronic, persistent neuropathic might require more heroic measures including replacement of lost neural populations and reestablishment of appropriate neurocircuitry. Nevertheless, some overlap in the goals of these requirements can be envisioned, for example, the provision of neurotrophic or neuroprotective molecules for the attenuation of hyperexcitability in acute pain or replacement of lost inhibitory neurocircuitry in chronic pain. Thus, this review will examine the history and development of the various cell types and paradigms, which run the gamut from primary tissue fragments to engineered stem cell lines, that have been taken in various models of chronic pain in order to identify breakthrough approaches in the treatment of these debilitating conditions.

During the past three decades, cell therapy as an approach to treat pain has progressed from a hypothesis for a method for modulating pain processing to the development of the first human cell sources that are being tested in clinical pain treatment. The near future will likely provide new 
challenges for the implementation in a wider audience of those who suffer chronic pain, considering problems common to all forms of cell transplantation, that is, immune rejection versus long-term survival and efficacy in the human host; dependable, well-characterized cell sources for grafts; cells that can safely integrate into or near the CNS, without danger of tumors or significant, deleterious effects; the ability to control the antinociceptive output of cell grafts, ideally increasing with the cyclic episodes of pain efficacy in a wide variety of pain causalities. However, cell therapy for pain offers much promise as a replacement or adjunct to current clinical methodologies, once the mechanisms of pain are well understood, so that such bioengineered cellular tools can be used appropriately. Although it is likely that the majority of the cell types grafted thus far are functioning much like a cellular minipump, providing neuroprotective and neurotrophic agents in the damaged CNS, more studies to implement lost neuronal circuitry to modulate pain need to be accomplished. Future studies will likely better define the processes and mechanisms that will lead to improved selection of cell types and trophic agents which can be utilized in combination to provide improved therapeutic outcomes following disease and injury to the nervous system that leads to debilitating pain.

\section{Problem of Chronic Neuropathic Pain in Various Disease States and PNS/CNS Injuries}

The treatment of neuropathic pain is perhaps one of the most difficult problems in modern clinical practice. In addition to affecting a large population, it is a staggeringly heterogenous diagnosis with multiple etiologies which respond in varied manners to a myriad of treatments. Current pharmacologic treatments often prove ineffective, must be used at impractical dose levels, or have unacceptable side effects.

While the prevalence of neuropathic pain had previously been conservatively estimated at $0.6 \%$ of the U.S. population [1], better definition, understanding and recognition of this diagnosis has led to a more realistic prevalence of $7-8 \%$, recently reported in Europe [2,3]. A recent review by the Neuropathic Pain Special Interest Group of the International Association for the Study of Pain (IASP) estimated the overall prevalence of neuropathic pain at 3.3 to $8.2 \%$ [4]. However, due to the large variation in reported prevalence and incidence, they also recommended further research efforts regarding the development of standardized methods for identification and assessment of neuropathic pain. Neuropathic pain usually presents with allodynia, pain felt in response to a normally innocuous stimulus, and hyperalgesia, increased sensation of suprathreshold nociceptive stimuli [5]. It is often associated with uncomfortable dysesthesias and may have continuous and paroxysmal components.

\section{Etiologies}

Neuropathic pain may result from disorders of the central nervous system, the peripheral nervous system, or may be mixed. Nearly any traumatic event or disease leading to neuronal damage, or neuropathy, has the potential to cause neuropathic pain. Causes of neuropathy include trauma, vascular and metabolic disorders, infections, neoplasms, toxins, autoimmune disease, as well as genetic and nutritional deficiencies. As the individual causes of neuropathic pain are seemingly innumerable, we will mention only the more common etiologies.

Trauma, usually in the form of spinal cord injury and also due to direct peripheral nerve damage, is one of the leading causes of severe neuropathic pain [6]. Traumatic neuropathic pain affects nearly $60 \%$ of individuals with spinal cord injury [5]. Neuropathic pain is most common at or below the level of injury and is often diffuse and poorly localized [7], making this type of pain difficult to deal with for the individuals with SCI [8]. Few treatments are effective and most individuals have to continue to leave with persistent pain [9]. While there are several pharmacologic agents that have shown success in clinical trials [10], the side effects are often ill tolerated at the dosages needed for relief.

One of the most common peripheral causes of neuropathic pain is diabetes. Diabetes mellitus is one of the most prevalent diseases in the United States, affecting 25.8 million ( $8.3 \%$ of the population) [11]. Nearly 70 percent of those with diabetes have diabetic peripheral neuropathy, which can lead to severe neuropathic pain of the distal extremities.

There are many infectious causes of peripheral neuropathy, including viral and bacterial etiologies. Viral infections are more common and usually result in more severe neuropathic pain. They include herpes varicella-zoster (shingles), Epstein-Barr virus, cytomegalovirus, and herpes simplex. The human immunodeficiency virus (HIV) can cause several different forms of neuropathy, including a rapidly progressive, painful polyneuropathy affecting the distal extremities which is often the first clinically apparent sign of HIV infection [12]. Lyme disease, diphtheria, and leprosy are bacterial diseases characterized by extensive peripheral nerve damage. Neoplasms can create neuropathic pain due to direct nerve compression and/or infiltration. While in a pure sensory nerve, these may be surgically resected; cases involving motor nerves or plexi are not amenable to surgical therapy and must be managed by pharmacologic or neuromodulatory treatments. Radiation, certain chemotherapeutic agents, and paraneoplastic syndromes can also result in peripheral neuropathy.

Toxins can result in a heterogeneous group of peripheral neuropathies. Those exposed to heavy metals, such as arsenic, lead, mercury, thallium, or industrial toxins, as well as certain therapeutic drugs in the anticonvulsant, chemotherapeutic, antiviral, and antibiotic classes, can also cause peripheral neuropathy and neuropathic pain. Nutritional deficiencies, in particular thiamine deficiency due to its prevalence amongst alcoholics, may also result in peripheral neuropathy. Trigeminal neuralgia is an excruciating cause of facial pain but is usually amenable to surgical vascular decompression of the nerve. Central neuropathic pain can be caused by multiple sclerosis and certain stroke syndromes [13]. Genetic and autoimmune neuropathies are rarer but 
add to the overall population of those with neuropathic pain.

\section{Treatment}

Given the widely diversified causes of central and peripheral neuropathy that can lead to neuropathic pain, it becomes much clearer as to the difficulty in treating this diagnosis. Clearly, the underlying condition is treated first, followed by symptomatic treatment of the pain. Unfortunately, only a dismal $40-60 \%$ of patients with neuropathic pain achieve partial relief. A significant roadblock of the treatment dilemma has been the difficulty with the most appropriate animal model to use for basic research, as well as the disconnect between behavioral outcomes examined in animal studies and those reported in the presentation of pain in a clinical setting [14].

In an effort to clarify the existing therapeutic paradigm for neuropathic pain, recent guidelines have been derived for pharmacological therapy [15-18]. These have combined evidence from randomized controlled trials with expert opinion and currently offer the clearest treatment paradigm. While certain drugs work best for specific indications, likely due to the mechanism of that disease etiology, it is becoming clearer that a combination of pharmacologics, adjuvant treatment and neuromodulation are usually needed to attain adequate pain relief [19-21].

Despite multiple therapeutic options, the treatment of neuropathic pain remains difficult and inconsistent. While combination therapy and an increasing number of adjunct therapies assist in treating intractable pain, there still remains no cure. Pain despite standard treatment due to poor efficacy, unacceptable side effects, and disease escalation demand continued investigation and development of new technologies to treat neuropathic pain.

\section{Pain Classification}

In the clinical setting, a broad classification of pain is made in order to differentiate between nociceptive and neuropathic pain types. This is a critical distinction because these pain types are dependent on partly different underlying mechanisms, and therefore, they usually require different treatment strategies. Arriving at an accurate neuropathic pain diagnosis is not straight forward, and this problem has been recognized both in pain research and in clinical pain management settings. To address this problem, the International Association for the Study of Pain (IASP) has proposed a modification of the present pain taxonomy. Neuropathic pain is currently defined as "pain initiated or caused by a primary lesion or dysfunction in the nervous system" [22]. However, Treede and colleagues $[23,24]$ recently suggested eliminating "dysfunction" from the definition and instead redefine the neuropathic pain definition to "pain arising as a direct consequence of a lesion or disease affecting the somatosensory system." In order to standardize the classification into neuropathic and nonneuropathic pain, they recommended differentiating pain into "definite," "probable," and "possible" neuropathic pain. The following criteria were proposed to be required for "definite" neuropathic pain: (1) pain distribution consistent with injury to the peripheral nervous system (PNS) or the central nervous system (CNS); (2) history of an injury or disease affecting the PNS or CNS; (3) abnormal sensory signs within the body area corresponding to the injured area of the CNS or PNS; (4) a diagnostic test confirming a lesion or disease in these structures.

These criteria are applicable to many neuropathic pain conditions. However, in conditions with multiple concomitant pain types after CNS injuries, such as in SCI-related pain, distinguishing between neuropathic and nociceptive pain may be more difficult when pain is located in an area below the lesion but with partial sensory preservation. For such pain locations, abnormal sensory findings may not indicate a neuropathic pain diagnosis, since these will be present in the painful area regardless of whether pain is nociceptive or neuropathic [25].

Basic research studies have identified multiple underlying mechanisms of neuropathic pain and designed interventions to target them. However, significant knowledge gaps exist regarding the best methods to characterize pain subgroups (phenotypes) and their relationship to the underlying pain mechanisms in pain patients. A precise diagnosis is critical to the development of more effective treatments that are tailored to specific underlying mechanisms. Because neuropathic pain is dependent on multiple mechanisms [26], this knowledge gap is a significant barrier to translation of basic research finding into successful management of neuropathic pain.

The determination of clinical pain phenotypes is a promising way to classify pain types. This process may include statistical grouping of pain characteristics [27]. For example, a combination of the descriptive adjectives "burning," "tingling," "pricking," "shooting," and "freezing" pain, and evoked pain, differentiated between neuropathic and nonneuropathic pain in 618 patients with diabetic neuropathic pain, idiopathic neuropathic pain, or post-herpetic neuralgia or nociceptive osteoarthritis pain, or low back pain [28]. Another method used for defining clinical pain phenotypes includes quantitative sensory testing (QST; $[29,30])$. Measurement of detection thresholds for tactile stimuli determines large-fiber and dorsal column-mediated function, and thermal detection and pain thresholds determine small-fiber and spinothalamic tract-mediated function. Thus, QST may facilitate the comparisons with basic research studies, since these studies often assess behavioral, evoked nociceptive responses.

\section{Potential Strategies for Cell-Based Interventive Therapies: Rationale}

6.1. Cellular Minipumps for Treatment of Pain. The earliest studies using cell transplants for pain were originally developed from the concept of descending inhibitory neurotransmitter modulation of sensory information [31], and that these same agents, such as catecholamines and opiates, released by cell grafts [32-36] after injury, could provide antinociception. Projections from midbrain, locus ceruleus, ventromedial, and ventrolateral medulla directly or 
indirectly terminate at spinal level to modulate incoming nociceptive signals. In addition, dorsal horn interneurons provide inhibitory influences at the same termini. A variety of neurotransmitters, peptides, opioids, and lately neurotrophins, such as BDNF, have been implicated in spinal inhibition. These include the endogenous neurotransmitters serotonin (5HT), noradrenaline, and gamma-aminobutyric acid (GABA); the endogenous opioids $ß$-endorphin, enkephalins, cannabinoids; endogenous peptides such galanin, and neurotrophins such as BDNF. Many of the commonly used pharmacologic therapies target these agents' receptors and reuptake mechanisms to increase or imitate their presence in acute and chronic pain. But it was recognized as early as 1980s [36] that these agents could be supplied by grafts of autologous adrenal medullary tissue [37] or chromaffin cells [38] which had been purified from adrenal tissue, and transplanted in a chronic arthritic pain model [39], after nerve transection [40], or peripheral nerve injury and painful neuropathy $[41,42]$ to attenuate behavioral hypersensitivity. Where a similar strategy using pharmacological agents and mechanical intrathecal delivery might be considered, intrathecal and/or intra administration cerebroventricular of opioids is limited by cost, the need for specialized maintenance and mechanical malfunctions if implantable drug delivery systems, or by the risk of bacterial contamination and ambulatory constraints when repeated daily injections via an intrathecal access port are used [43]. Intrathecal cell therapy secreting these same antinociceptive agents can be seen as an advantage. Since it was also noted that minimal immunosuppression was all that was required for good graft function and survival in the immune-protected nervous system [44], such studies led to the early initiation of clinical trials for chronic cancer pain with this cell transplant approach $[42,45,46]$.

\section{Early Use of Cell Therapy}

7.1. Primary Adrenal Chromaffin Tissue and Cells. Some of the earliest studies utilized primary chromaffin cells in a rat model of neuropathic pain [41]. Chromaffin cells contain a cocktail of antinociceptive agents, peptides, and neurotrophins $[47,48]$. These chromaffin cell grafts were placed either in midbrain structures [38], or in the lumbar subarachnoid space after partial chronic constriction injury (CCI) to the sciatic nerve [42], or after injection of formalin in the rat's hindpaw [49] for the antinociceptive effect. Many studies have sought to elucidate the agents released by these chromaffin grafts that might serve an antinociceptive role. These primary chromaffin cells grafts raise the levels of CSF met-enkephalin [32], increase CSF levels of catecholamines [50], and reduce morphine cross-tolerance [51] when used with morphine for pain. Changes in the spinal cord induced by nerve injury are attenuated by chromaffin grafts, such the induction of spinal NADPH-diaphorase [52] and cGMP [53], spinal c-fos induction [54], NMDA-induced hypersensitivity [55], and the loss of endogenous inhibitory GABA synthesis in the dorsal horn [56] that accompanies nerve injury. It is likely that adrenal transplants also block short-term spinal nociceptive facilitation, illustrated by the reduction in the c-fos induction by formalin in the presence of chromaffin grafts [57], probably by stimulating some persistent cellular process, such as increasing the descending inhibitory controls that regulate the firing of subpopulations of spinal cord nociresponsive neurons with release of opioids from grafted chromaffin cells, inhibitory modulation that may be an important determinant, but not the only one, of their analgesic effect [58]. To be able to use chromaffin cell therapy in humans, adrenal chromaffin cell grafts were prepared from xenogenic bovine sources and tested for antinociception after nerve injury $[35,59]$. Such sources of primary bovine chromaffin cells have been safely used in initial trials with human patients with intractable cancer pain $[60,61]$. But such primary tissue sources for the purification and use of chromaffin cells are not likely to be homogeneous, since they are often obtained from multiple donors. The ability to use and manipulate cell lines as a defined and stable source would be an alternate for eventual use in cell therapy.

Adult human chromaffin tissue has also been transplanted in humans for cancer pain [62], but when the immune response in the human host is examined after human chromaffin grafts, one conclusion is that further purification and/or the immunoisolation of tissues grafted in the CNS will be necessary when using these primary adult human adrenal sources, particularly when the possibility of long-term and repeated grafting is considered [63]. However, there are recent reports [64] of successful human fetal adrenal transplant to treat pain associated with rheumatoid arthritis, and in a rat model of partial nerve injury [65], certainly suggesting that fetal or precursor chromaffin tissue could be used as an antinociceptive source $[66,67]$. But using such primary tissue sources for the further purification [68] for successful cell therapy necessitates immunosuppression of the human host, such that examination of encapsulation technologies of grafted cells continued in many rat and human studies (Figure 1).

7.2. Clinical Trials Utilizing Cell Therapy for Neuropathic Pain. As mentioned above, cell therapy utilizing intrathecal adrenal chromaffin grafts to treat cancer pain was initiated in the early 1990s [41, 46, 61], which reported long-lasting pain relief, in correlation with met-enkephalin release into the CSF [43]. Typically not all late-stage cancer patients respond well to systemic opioids for pain management, with adverse effects and poor pain control [69], and hence requiring intrathecal delivery. The efficacy of this cell therapy technique depends on the ability of those cells to produce analgesic opioids and on the immuno-privileged property of the central nervous system, in which rejection risks are limited [70]. Before inclusion in an open Phase II trial, all the cancer patients to be grafted with human chromaffin cells had their pain controlled by daily intrathecal (I-Th) morphine administration. Out of the 12 patients who profited from enhanced analgesia with long-term followup (average 4.5 months), five no longer required the I-Th morphine (with prolonged interruption of systemic opioids as well), two durably decreased I-Th morphine intake, and five were stabilized until the end of their followup. Durable decline and 


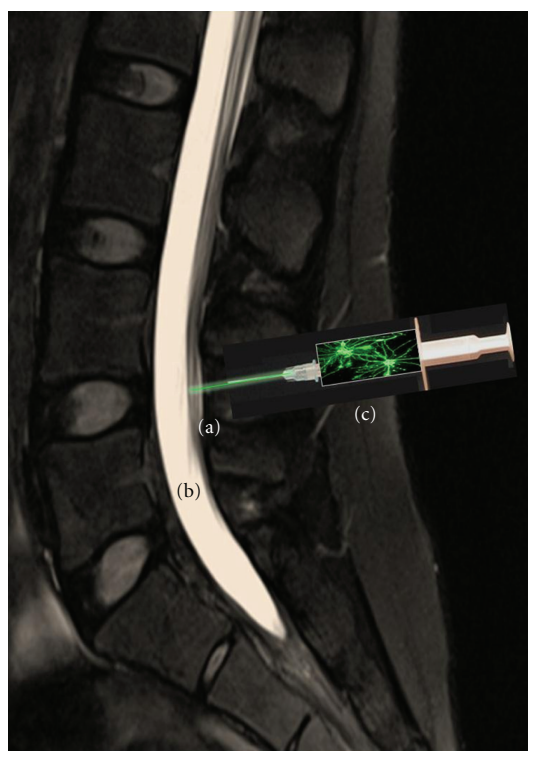

FIGURE 1: Model of lumbar subarachnoid injection of human neurons near the human spinal cord. MRI image of the human spinal cord (a) with a lumbar puncture of the subarachnoid space adjacent to the cord (b), and injection of cells, such as the GABAergic human neuronal hNT2.17 cells (c) for pain relief, as delivered by syringe (d). A similar technique has been used in all pre-clinical animal experiments and clinical studies with human chromaffin cell injections for pain.

stabilization were interpreted as indicative of analgesic activity by comparison with the usual dose escalation observed during disease progression, related to increased CSF metenkephalin levels associated with the grafts [71]. The grafts were tolerated, and there is evidence of long-term survival [72], despite the presence of CSF lymphocytes, where single treatment failure and three of four cases of partial efficacy occurred in grafts where CSF lymphocytes were present, indicating that impairment of the local immunosuppressive balance can lead to activation of host CSF CD4 T cells and drive a rejection process when grafts are not encapsulated [63]. It was concluded that graft immunoisolation, by using cell encapsulation, seems to be unavoidable in spite of the graft site [70]. Such ultimately failed clinical trials provided a better understanding of the limits (at that time) for this approach $[43,62,72,73]$. Adult human chromaffin tissue has also been transplanted in humans for cancer pain [62], but when the immune response in the human host is examined after human chromaffin grafts, one conclusion is that further purification and/or the immunoisolation of tissues grafted in the CNS will be necessary when using these primary adult human adrenal sources, particularly when the possibility of long-term and repeated grafting is considered [63]. However there is a recent report [64] of successful human fetal adrenal transplant to treat pain associated with rheumatoid arthritis, certainly suggesting that fetal or precursor chromaffin tissue could be used as an antinociceptive source [66]. But such primary tissue sources for the purification and use of chromaffin cells are not likely to be homogeneous, since they are often obtained from multiple donors. The ability to use and manipulate stable antinociceptive cell lines as a defined source has provided a rich literature for their experimental use in cell therapy (Table 1).

\section{Strategies for the Creation of Immortalized Cell Lines: Rationale/Studies}

8.1. Naturally Occurring (Tumor) Cell Lines. A cell line has the ability to be expanded in vitro, is stable enough in its phenotype to be characterized in vitro and after grafting; and can be used for in vivo transplant. The archetypal adrenal medullary cell line is the rat PC12 cell line, first established from a transplantable rat adrenal pheochromocytoma [74], which was shown to respond to NGF with reversible loss of mitotic activity and differentiation to a neuronal phenotype. This natural, oncogenic cell line has been used as a model to bioengineer the addition of the gene [75] for the analgesic [76] peptide histogranin ( $\mathrm{SHG}$ ) which acts as an antagonist for the excitatory NMDA receptor, as SHG can enhance the antinociceptive properties of grafted cells, such as chromaffin transplants [77]. Although originally reported to lack phenylethanolamine N-methyltransferase (PNMT) and epinephrine synthetic capability [74], further characterization [78] suggests both PNMT activity and epinephrine synthesis in PC12 cells. Although this cell line has often been examined for its response to manipulation to agents, such as morphine analogs important in pain modulation [79], it has also been tested as a grafted catecholamine source to test cell therapy for pain relief [80]. However, PC12 cells tend to form tumors, rather than to integrate and release antinociceptive agents. Grafts of the mouse B16 F1C29 melanoma cell line, which also release catecholamines, was able to reduce pain behaviors in the tail-flick model when accompanied by morphine [81], but again, such grafts are tumorigenic, and their transplant can itself induce pain behaviors [82]. The monaminergic human NB69 neuroblastoma cell line was able to reduce neuropathic pain in a nerve injury model [83], presumably related to serotonin release from the grafts, but the tumorigenic potential is a consideration with a nondifferentiated tumor line. Other studies with implantation of tumor-derived cell lines, like AtT-20 or AtT20/hENK [84], Neuro2A [85], Neuro2A/POMC [86], or P19 [87], that overexpress opioid peptides have been attempted, but such grafts would also carry the risk of tumor formation.

Although the ability of opioids to provide pain relief with SCI remains controversial, the release of enkephalin-like molecules from genetically modified cell grafts, such as AtT20/ENK cells, as therapeutic was an early strategy [84, 88]. One goal of such a opioid-based strategy would be to reduce the side-effect of tolerance that develops with morphine and its analogs [84] (Table 2).

8.2. Conditional Immortalization to Create Cell Lines. Retroviral infection of neural precursors, when cells are actively proliferating, with an immortalizing gene sequence in vitro, is a strategy applicable to a variety of cell types that might be useful for transplantation [89], and especially the neural phenotype with v-myc [90] or the wild-type SV40 
TABle 1: Primary tissue used for cell therapy.

\begin{tabular}{|c|c|c|}
\hline Source & Pain model & Results \\
\hline $\begin{array}{l}\text { Primary cells/tissue: } \\
\text { Adrenal-rat } \\
{[49,57,58,219,245-249]} \\
\text { Bovine } \\
{[35,59,247,250-254]} \\
\text { Encapsulated bovine } \\
{[247,255-258]} \\
\text { bovine scaffolds [259] } \\
\text { Porcine } \\
\text { [253, 254, 260-262] } \\
\text { Encapsulated porcine [262] } \\
\text { Human } \\
{[62,67,71,263,264]} \\
\text { Human encapsulated [67] }\end{array}$ & $\begin{array}{l}\text { Acute [247] } \\
\text { Midbrain [38] } \\
\text { Formalin [54, 58, 247, 249, } \\
253,260,261] \\
\text { Nerve injury } \\
{[46,57,67,256,262]} \\
\text { Dorsal rhizotomy [246] } \\
\text { Excitotoxic SCI } \\
{[219,255,265]} \\
\text { Hemisection SCI [245] } \\
\text { Human Cancer } \\
{[64,71,266,267]} \\
\text { Arthritis }[56,65,268]\end{array}$ & $\begin{array}{l}\text { (i) Reduced "excessive grooming" behaviors [219] } \\
\text { (ii) Reduction or stabilization in complementary opioid intake in human } \\
\text { cancer [71] } \\
\text { (iii) Reductions in both fore- and hindlimb mechanical and thermal allodynia } \\
\text { [245] } \\
\text { (iv) Failed antinociception after intraventricular transplant [256] } \\
\text { (v) Reduces edema, anterograde axoplasmic transport [249] } \\
\text { (vi) Restores spinal GABA-ir decreased spinal c-Fos [58, 253] } \\
\text { (vii) Failed antinociception [247, 247, 269-271] } \\
\text { (viii) Reduced cold or TA/TH behaviors [67, 219, 262] } \\
\text { (ix) Reduced tonic pain behaviors [261] } \\
\text { (x) Delayed, reduced self-directed pain behaviors [246] } \\
\text { (xi) Antinociceptive effects on A-delta and C-fiber-mediated responses [59] } \\
\text { (xiii) Long-term proenk and tyrosine hydroxlylase in grafts [248] } \\
\text { (xiv) Reduce forelimb/hindlimb allodynia [245] }\end{array}$ \\
\hline
\end{tabular}

TABLE 2: Naturally occurring (tumor) cell lines.

\begin{tabular}{lll}
\hline Source & Pain model & Results \\
\hline Tumor Cell Lines: & & \\
$\begin{array}{l}\text { Rat PC12 [74] } \\
\text { Encapsulated PC12 [272] }\end{array}$ & $\begin{array}{l}\text { Tail-flick or chemical } \\
\text { induction }\end{array}$ & (i) Analgesic $[85,88]$ \\
Mouse B16 [81] & {$[81,84,85,87,88]$} & (ii) Reduced opioid tolerance [84] \\
Human NB69 [83] & Acute $[81,84,85,88,273]$ & (iii) Antinociceptive [81, 83, 84, 273, 274] \\
AtT-20 [84, 273] & Partial nerve injury (CCI) & (iv) Reduced cold allodynia [83, 272] \\
Encapsulated AtT-20 [85], & {$[83,272,274]$} & \\
Neuro2A [85] & Formalin [87] & \\
Encapsulated Neuro2A [1327] & & \\
P19 [87], & Tail-flick or chemical & (i) Increased ACTH release with TET-ON stimulation [86] \\
\hline Bio-engineered-AtT-20/hENK [84, 273] & induction $[84,273]$ & (ii) Reduced Phase II formalin-induced responses [75] \\
Encapsulated Neuro2A/POMC [86] & & \\
Autologous rat macrophages/proENK [274] & Formalin [75] & \\
PC12/SHG peptide [75] & & \\
\hline
\end{tabular}

large $\mathrm{T}$ temperature-sensitive antigen (tsTag) oncogene [91]. Immortalization with tsTag can result in cell lines capable of undergoing proliferation at permissive temperature $\left(33^{\circ} \mathrm{C}\right)$ and differentiation under appropriate temperature conditions (nonpermissive; $39^{\circ} \mathrm{C}$ ) $[92,93]$. Infection of precursors with the temperature-sensitive allele of Tag (tsTag) in vitro [94] and in vivo [95] has allowed cells to undergo growth arrest and continue differentiation under nonpermissive temperature $\left(39^{\circ} \mathrm{C}\right)$ conditions. These differentiating temperatures are possible both in vitro, allowing transformed cells to revert to a near-normal primary cell phenotype, as well as in vivo, where CNS transplant temperatures are near $39^{\circ} \mathrm{C}$ [96], and tumors are not formed because the immortalizing gene is not expressed. Thus, conditional immortalization with the oncogenic tsTag construct incorporates the advantages of cell lines, including the convenience of growing large quantities that can be characterized and safety tested and the ability to also genetically engineer-in the expression of additional therapeutic molecules, while reducing the disadvantages of tumor cell lines.

Though describing engineered-cell grafts as "biological minipumps" for secretion of neurotrophic or antinociceptive agents has only been recently discussed [97, 98], the practicality has been examined for at least the last 25 years $[99,100]$. But, the same strategy, using engineered cells that might secrete potentially antinociceptive molecules when placed in the lumbar subarachnoid space after PNS or CNS injury, much like the primary adrenal chromaffin cells and opioid cell lines described above, has seen few applications for use in chronic pain $[81,84]$. But the potential application of such cell line grafts for the diverse problems with neuropathic pain in human therapy is significant [101], given the paucity of homogeneous primary tissue. Unlike primary or immortalized chromaffin cells, the engineered cells being tested in a variety of models of acute and chronic pain were initially neuronal epithelial precursor cell lines derived from the rat medullary raphe. Two lines that have been bioengineered, called RN46A, and RN33B were isolated from embryonic day 12.5 (E12.5) rat brainstem after immortalization with the SV40 tsTag sequence $[102,103]$. Although they were derived from the same primary cultured neuronal precursors, there are significant differences in their phenotypes: RN46A cells are an early serotonergic precursor neuronal cell line, with the potential to switch developmental phenotype [102], depending on the timing and exposure to a variety of neurotrophic and other factors, including 
BDNF [104], CNTF [105], GDNF [106], and ACTH [107]. This cell line was made to synthesize and secrete the neurotrophin BDNF, by the addition of the sequence for rat BDNF to its genome, causing the cells to have improved survival in vitro and in vivo, and develop a permanent serotonergic (5HT) phenotype [108]. Since additional 5HT might be postulated to have a beneficial antinociceptive effect on neuropathic pain [109] differentiated cells were placed in a lumbar subarachnoid location after sciatic nerve chronic constriction injury (CCI). Transplants of this serotonergic cell line 46A-B14, placed two weeks after CCI and the development of severe hypersensitivity to thermal and tactile stimuli were able to potently and permanently reverse the symptoms of neuropathic pain [110], compared to grafts of the same cells which did not receive the BDNF gene and did not synthesize 5HT in vitro or in vivo. Transplants of other cell lines genetically engineered to synthesize and secrete potentially antinociceptive molecules such the inhibitory peptide galanin [111], the neurotrophin BDNF [112], and the inhibitory neurotransmitter GABA [113] have all been tested after CCI and the induction of neuropathic pain, and each has reversed the thermal and tactile allodynia and hyperalgesia that develop after CCI. Each engineered cell line is characterized for its particular gene expression under permissive and nonpermissive temperature conditions, since the cell lines are usually transplanted immediately after proliferation at $33^{\circ} \mathrm{C}$. Following placement of the differentiating cells in the subarachnoid space, especially in models of pain, both cell graft survival and continued expression of the antinociceptive phenotype were examined in vivo. An example of such an engineered rat neuronal cell line, the RN33-GAD67, which synthesizes and secretes GABA after differentiation in vitro and transplant in vivo [113] in the CCI pain model, where GABA is synthesized after differentiation in these cells. But such an effect for neuropathic pain seems to require an early transplant time, since grafts of these rat neuronal GABA cells are less effective when placed late after nerve injury [114]. With both types of behavioral hypersensitivity, thermal and tactile hyperalgesia, rat GAD67 grafts cause immediate reversal of hypersensitivity when the behaviors are measured one week later. Such potent reversal is common to each of the engineered cell lines used for therapy after partial nerve injury models, and more recently with SCI models [115-118], especially thermal hyperalgesia. But using the CCI model of neuropathic pain and near-identical transplant numbers and experimental conditions for all these studies has identified the rat GABA- and 5HT-cell lines as especially efficacious, since attenuation of hypersensitivity is more potent and permanent in the presence of these graft phenotypes, although early transplant time seems to be favored in the CCI model [119]. But other antinociceptive cell types have also been conditionally-immortalized to test their usefulness in eventual clinical applications.

Mitotic cells found in embryonic medullary adrenal tissue can also be conditionally immortalized with the tsTag oncogene so that the differentiated cell type keeps many of the phenotypic features of primary chromaffin cells. Conferring immortalization with the SV40 large T antigen expression has a variety of effects on cells when the wild-type large $\mathrm{T}$ protein is present, including binding of large $\mathrm{T}$ and inactivation of the growth suppressors pRB, p53, and SEN6 $[120,121]$, a decrease in $\mathrm{G} 1$ and increase in G2 and $\mathrm{M}$ cell cycle phase duration [122], and the ability of large $\mathrm{T}$ antigen to block the differentiation process [123]. However, after immortalization with the temperature-sensitive allele tsTag [94, 124], immortalized cells resume the stage of life span and function of an uninfected cell when they are shifted to nonpermissive temperature conditions [125]. These cells at the nonpermissive temperature have lost the ability to drive cell proliferation, since the large $\mathrm{T}$ antigen is labile at the higher temperature conditions [126] and the T antigen is not able to drive mitosis in cells immortalized with the construct, and differentiation is favored [94, 124]. In general, SV40 large $\mathrm{T}$ antigen-immortalized cell lines retain the phenotype of the differentiated lineage of the parent. Cell lines generated with the SV40 large $\mathrm{T}$ antigen retain contact inhibition in vitro $[127,128]$ and do not produce tumors or induce immune rejection even when injected into nude mice [129] or rats [130-137].

Rat and bovine chromaffin cells immortalized with tsTag in vitro [138] express many of the markers found in primary chromaffin cells and when differentiated in vitro, as the oncogenic Tag protein is degraded and mitosis ceases, these markers remain and are able to be regulated by continued differentiation, by agents such as dexamethasone and by stimulation of the cAMP pathway with forskolin, mechanisms seen in primary chromaffin cells [138]. Such immortalized chromaffin cells are stable and appear homogeneous, suggesting that they could be useful for further genetic manipulation and as a source for transplant studies in vivo [139].

The cell biology and developmental responsiveness during differentiation of chromaffin cells [140] reveals clues to the differentiation program of conditionally immortalized chromaffin cell lines in vitro. The enzyme tyrosine hydroxylase (TH; EC1.14.3.x) catalyzes the rate-limiting step [141] in the biosynthesis of catecholamines in chromaffin cells in the adrenal medulla $[142,143]$ and has been used as one of the antigenic markers for the mature chromaffin phenotype of primary rat and bovine chromaffin cells in vitro [144], as well as $\mathrm{D} \beta \mathrm{H}$ and PNMT. Both the rat RAD5.2 and bovine BADA. 20 chromaffin cell lines express these catecholamine enzyme immunoreactivities at both permissive (low levels) and nonpermissive temperatures, when the cells are proliferating or differentiating, respectively, though levels of the $\mathrm{D} \beta \mathrm{H}$ enzyme appears to change with differentiation at nonpermissive temperature $\left(39^{\circ} \mathrm{C}\right)$. Tyrosine hydroxylase (TH) expression is not upregulated in the rat chromaffin cell line but seems to be a feature of immortalized bovine chromaffin cell in vitro [138]. But further increased catecholamine enzyme expression in the chromaffin cell lines requires treatment with forskolin and/or dexamethasone during differentiation, since differentiation at $39^{\circ} \mathrm{C}$ is in serum-free medium [138]. Differentiated primary chromaffin cells from rat $[145,146]$ and bovine [34] sources have often been used to study the synthesis and release of the catecholamine neurotransmitters norepinephrine and epinephrine in vitro. However, even with upregulation of enzyme expression, these conditionally immortalized chromaffin rat 
and bovine cells do not synthesize catecholamines under in vitro conditions [138]. Since chromaffin cell lines probably require an adequate substrate interaction for a completely normalized chromaffin phenotype, the absence of detectible catecholamine synthesis in differentiated RAD5.2 and BADA.20 cells may be due to removal from their fibroblast environment. Another possible, and more likely, explanation for the absence of catecholamine synthesis is a continued low level of Tag expression, even though it is greatly reduced after three weeks of differentiation at $39^{\circ} \mathrm{C}$. It is possible that even a low level of Tag suppresses some normal cellular functions, such as neurotransmitter synthesis.

This attempt at conditional immortalization of chromaffin cells using the tsTag oncogene and retroviral infection in vitro, demonstrating continual cell lines retaining many features of the mature chromaffin cell phenotype. The availability of conditionally immortalized chromaffin cell lines for a variety of studies, including their use as transplants in various models of neuropathic [139], reflects the growing interest in the development of molecular biological techniques of cellular therapy for treating neuropathic pain, but further attempts to develop the immortalization technologies were needed.

8.3. Reversible Immortalization to Create Cell Lines. The ability to reverse immortalization in a tightly controlled manner was the logical next step in the creation of cell lines from rare phenotypes [147]. But such reversible-immortalized cell lines that might be used for antinociception have been little studied [148]. The generation of chromaffin cell lines, utilizing the temperaturesensitive allele of SV40 large T antigen (tsTag) are able to reverse neuropathic pain after transplant in the spinal subarachnoid space after CCI of the sciatic nerve [139]. Even with near 100\% disappearance of Tag in the grafts within a few weeks after transplant [139], oncogene expression in vivo remains a potential possibility and such cells would not be an appropriate strategy for safe clinical use in humans.

Studies exploiting sitespecific DNA recombination and Cre/lox excision have suggested that cells can be targeted in vitro [149] and in vivo [150] for removal of deleterious genes, including the Tag sequence [151]. Reversible immortalization with Tag and Cre/lox technology was first reported with human fibroblasts by Westerman and Leboulch [152] and more recently with human myogenic cells and hepatocytes [153] and hepatic progenitors [154]. In these latter studies, Cre was introduced by transfection or infection, inefficient methods that may lead to a lack of disimmortalization and the loss, through the subsequent selection of disimmortalized cells, of a significant part of the population. Moreover, in vivo excision is not possible. Use of a vector that allows a silent, but inducible, form of Cre is preferred for the timed excision of the oncogene.

A number of chimeric Cre-containing fusion proteins, especially fusions with the ligand-binding domains of steroid receptors, have been created to utilize the binding by synthetic ligands to activate Cre [155]. CrePR1 is a fusion protein [156], consisting of the fusion of Cre and the ligand binding domain of a mutant human progesterone receptor
(hPRB891). Cre activity in the cells is activated by the binding of the steroid RU486, which in turn induces the translocation of CrePR1 to the nucleus where the Cre is active to excise the floxed sequences. The requirement for RU486 and the use of a mutated steroid receptor for disimmortalization would assure that if nondisimmortalized cells were transplanted, Cre would not be activated by circulating endogenous progesterone, a strategy used for inducible recombination with in vivo CNS studies [157].

It has been demonstrated [158] that embryonic rat adrenal chromaffin cells could be immortalized with a oncogenic tsTag construct, utilizing retroviral infection of these early chromaffin precursors, where the tsTag construct (tsATN) was flanked by loxP sequences. Following isolation of immortalized cells using positive neomycin selection, the cells were further infected with a retrovirus expressing the CrePR1 gene, which encodes a fusion protein which combines Cre activity plus the mutant human steroid receptor, hPRB891. Cultures of embryonic rat adrenal cells were immortalized with the tsA-TN retroviral vector encoding the loxP-flanked temperature-sensitive allele of SV40 large $\mathrm{T}$ antigen (tsA-TN), which included a positive/negative neo/HSV-TK sequence for selection with either G418 or gancyclovir, respectively.

A number of chimeric Cre-containing fusion proteins, especially fusions with the ligand-binding domains of steroid receptors, have been created to utilize the binding by synthetic ligands to activate Cre [155]. CrePR1 is a fusion protein [156], consisting of the fusion of Cre and the ligand binding domain of a mutant human progesterone receptor (hPRB891).

When immortalized chromaffin cells are disimmortalized with cre-lox technology to disimmortalize the chromaffin cells in vitro, complete removal of the Tag sequence before differentiation seems to allow neurotransmitter synthesis and a more normal phenotype [158]. Compared to downregulation of the tsTag protein in conditionally immortalized rat chromaffin cells, disimmortalization in vitro in these disimmortalizable rat chromaffin cells, called the loxtsTag/CrePR1/RAD chromaffin cell line, the Tag protein was completely and efficiently removed by 10 days of treatment with RU486, followed by incubation with the antibiotic gancyclovir [158]. Cells which were not disimmortalized, were removed by their continued expression of the thymidine kinase (TK), which is toxic in the presence of gancyclovir [159].

Irreversible removal of a potentially subverting oncogene by its excision using the Cre/Lox system might thus be a clinically useful strategy, especially since the core temperature of humans is lower than that of rodents, and the expression of a temperature-sensitive antigen might not be completely blocked in a clinical context [152, 160-164]. Note that in this respect, use of moduletable Cre activity that can be activated by the synthetic steroid RU486 $[156,157]$ has added a means to select the timing of disimmortalization and render the overall procedure more flexible and efficient. Interestingly, the disimmortalized rat chromaffin cells had very increased expression of tyrosine hydroxylase $(\mathrm{TH})$, the rate limiting enzyme for catecholamine synthesis, in vitro. This was 
TABLE 3: Strategies for creating cell lines.

\begin{tabular}{|c|c|c|c|}
\hline Source & Model & Results & $\begin{array}{l}\text { Antinocicptive Molecule } \\
\text { Released }\end{array}$ \\
\hline $\begin{array}{l}\text { Conditionally immortalized Cell lines: } \\
\text { Embryonic rat Raphe/SV40tsTag } \\
{[102,103,275-277]} \\
\text { Embryonic rat DRG neuron, 50B11 } \\
\text { [90] } \\
\text { Human DRG neuron, HD10.6, } \\
\text { v-myc [278] } \\
\text { Embryonic rat and bovine } \\
\text { Chromaffin [138, 139] } \\
\text { Human embryonic Chromaffin } \\
\text { cells/tsTag [279] }\end{array}$ & $\begin{array}{l}\text { partial nerve injury } \\
\text { (CCI) [139] }\end{array}$ & $\begin{array}{l}\text { (i) Expressed capsaicin receptor transient } \\
\text { receptor potential vanilloid family-1 } \\
\text { (TRPV-1) and responded to capsaicin in } \\
\text { vitro [90] } \\
\text { (ii) Expressed sensory neuron-associated } \\
\text { transcription factors and exhibited capsaicin } \\
\text { sensitivity [278] } \\
\text { (iii) Antinociceptive [139] }\end{array}$ & (i) enkephalin? $[279,280]$ \\
\hline $\begin{array}{l}\text { Bioengineered rat Raphe/tsTag/ } \\
\text { BDNF }[110,211] \\
\text { Rat raphe/tsTag/galanin }[111] \\
\text { Rat raphe/tsTag/GAD67 [113] } \\
\text { Rat chromaffin/tsTag/Met-ENK } \\
{[165,170]}\end{array}$ & $\begin{array}{l}\text { Partial nerve injury } \\
(\mathrm{CCI})[84,110,113,158, \\
211,229] \\
\text { Formalin/c-fos } \\
\text { induction }[170] \\
\text { Hemisection SCI } \\
{[115-118]}\end{array}$ & $\begin{array}{l}\text { (i) Antinociceptive } \\
\text { [84, 110,113, 116, 119, 158, 211] } \\
\text { (ii) Restores dorsal horn GAD/GABA system } \\
\text { in CCI [229] } \\
\text { (iii) Only intrathecal, not intraspinal, grafts } \\
\text { of 5HT cells are antinociceptive [115] } \\
\text { (iv) Attenuates bilateral DH hypersensitivity } \\
\text { [117] } \\
\text { (v) Restores spinal serotonin, downregulates } \\
\text { the serotonin transporter, and increases } \\
\text { BDNF tissue content [118] } \\
\text { (vi) Reduce formalin-evoked c-fos } \\
\text { expression [170] }\end{array}$ & $\begin{array}{l}\text { (i) } 5 \mathrm{HT} \\
{[110,116-118,211,229]} \\
\text { (ii) BDNF }[110,118,211] \\
\text { (iii) GABA }[110,113] \\
\text { (iv) galanin }[111] \\
\text { (v) Met-enkephalin }[170]\end{array}$ \\
\hline
\end{tabular}

Reversibly immortalized Cell Lines:

Tetracycline-regulated of SV40 large

T-antigen (Tag) in human embryonic Partial nerve injury

stem (ES) cells and mice [147] (CCI) [158]

(i) Antinociceptive [158]

(i) enkephalin? [158]

Cre/lox-regulated Disimmortalizable

(ii) release norepinephrine

[158]

Embryonic rat chromaffin cells [158]

accompanied by 5 -fold increase in norepinephrine synthesis in vitro [158]. But these disimmortalizable rat chromaffin cells not only synthesize epinephrine after Tag excision, but they also apparently make increased catecholamine enzymes besides $\mathrm{TH}$, judged by qualitative immunohistochemistry for the enzymes compared to both nonexcised and those immortalized with only tsTag [138]. Also of importance, transplant of disimmortalized rat chromaffin cells was able nearly eliminate neuropathic pain in the CCI model of partial nerve injury, when compared to the injury alone or transplant of immortalized chromaffin cells. Rather than suggesting that antinociception is the result of catecholamine synthesis, release or secretion from grafted chromaffin cells, the existence of an equivalent functional effect by nondisimmortalized cells suggests that another agent or mechanism is responsible for reduction of neuropathic pain by these genetically manipulated chromaffin cells, at least in this model of pain. Even if chromaffin grafts do not make significant levels of catecholamines in vivo, the antinociception the grafts provide might be a result of other antinociceptive molecules synthesized and released by the cells, such as GABA or met-enkephalin. Presumably the increased norepinephrine phenotype recovered following excision of the oncogene by disimmortalized cells would function to advantage in cell therapy, but with disimmortalized rat chromaffin cell grafts no such advantageous effect could be demonstrated. Rather, the value of disimmortalization before transplantation is to provide a measure of safety, with the complete absence of the oncogene and prevention of even a remote possibility of viral transfer of the large $\mathrm{T}$ antigen in the host, after grafting such cells (Table 3).

8.4. Transgenic Opioid Expression in Immortalized Cell Lines. A further advance to model genetically modified, disimmortalizable chromaffin cell lines, is the work by Duplan and colleagues [165], who infected the disimmortalizable loxtsTag/CrePR1/RAD chromaffin cell line with constructs for the synthesis and secretion of the opioid met-enkephalin (met-Enk). These transgenic rat chromaffin cell lines expressed easily detectible met-ENK in vitro cells, which contained the met-ENK construct contained high levels of this opioid. The transgene also contained a neurotrophin growth factor (NGF) sequence for secretion of synthesized nascent protein, and chromaffin cells which contained the met-ENK transgene were able to secrete the highest levels of the met-ENK opioid from the cells. The value of opioids from chromaffin grafts in cellular therapy, especially for pain [166], has seen precedents in both animal $[32,62,167]$, and more recently, 
human clinical work $[43,71,165]$ when primary chromaffin tissue was used as a graft source. When these disimmortalizable loxtsTag/CrePR1/RAD chromaffin cells were grafted, by Duplan and colleagues, two weeks before injection of formalin into the hindpaw in a model of tonic pain [168, 169], those rats which had been given grafts of cells which secreted met-ENK did not develop the long-term response to formalin injection, compared to rats which had no grafted cells or those that had only received cells which were transgenic for the vector only [170]. Although it is not yet known how disimmortalization may influence the expression of transgene, such as the opioid met-ENK gene used here, irreversible removal of a potentially subverting oncogene by its excision using the cre/lox system might be a clinically useful strategy. Of course, immortalization of human chromaffin tissue with an oncogene, such as SV40Tag, is not likely with any potential for deleterious expression of SV40 proteins [171], but disimmortalization utilizing cre/lox site-directed removal of oncogenes in a growing technology to create useful graft sources for cell therapy for a variety of conditions $[160,161,172]$. There are a variety of possible oncogenic sequences that could be used for the reversible immortalization of human chromaffin cell lines, including v-myc [173]. However, the creation of reversibly immortalizable human chromaffin cell lines, perhaps from precursors [174], is still somewhat in the near future [175]. But such a homogeneous source will also allow for the manipulation of the chromaffin cell's genome to investigate the mechanisms of action responsible for cell grafts to repair the injured CNS environment. Similar immortalization of human chromaffin precursors and creation of human chromaffin lines $[65,67,73]$ presage the advent of cellular therapy as a therapeutic strategy that includes further development of human stem cell and progenitor/precursor cell lines [176].

\section{Current Strategies for Immortalized Cell Lines: Rationale/Studies}

9.1. Stem Cells. An increasing number of articles describing regenerative methods to improve function after injury and in certain disease states have appeared in the last few years. Most are related to transplants with stem cells [98], progenitors $[176,177]$, and bone marrow and nontransplants. Stem cell transplants can be ranked in the following descending order of preference; bone marrow-derived cells, neural stem cells, human umbilical cord blood cells, embryonic stem cells, and myoblasts. Bone-marrow-derived cells and human umbilical cord blood cell have been used for study in various disease fields. The nonstem cell transplantation group is made up primarily of islet cells, followed by biomaterials, and other cells or tissues from a variety of sources [178]. With their more limited multipotency, the use and potential of progenitor cells for improving function has still made significant progress recently [179-181], especially in the potential for renal and cardiac regeneration and reduction of ischemia [181-183]. But another critical potential to be fulfilled is in the area of the management of chronic, and especially neuropathic, pain.
9.2. Stem/Progenitor/Precursors (Animal Studies). In a recent report [184] utilizing the partial nerve injury with CCI to induce neuropathic pain, rat spinal embryonic progenitor cells (SPC) that used basic fibroblast growth factorB2 (FGF-2) for proliferation of the SPC in vitro were able to reduce thermal hyperalgesia after intrathecal transplant. Presumably, grafted cells had been induced to a GABAergic phenotype by FGF-2 in vitro and survived in its absence after transplant, maintaining their phenotype to modulate the neuropathic pain. The authors suggest that the grafts also increased the glycine content in the CSF of grafted animals, suggesting that if precursors could be induced to a phenotype that provides nociceptive inhibition, they would function much like cell minipumps, surviving in the intrathecal space. Also in the CCI model of peripheral pain, freshly isolated syngeneic marrow mononuclear cells were injected i.v. following the unilateral nerve injury and tactile allodynia and thermal hyperalgesia evaluated weekly. Marrow transplantation did not prevent pain, and 5 days after CCI all animals were equivalently lesioned. However, 10 days after CCI, rats that received marrow transplants demonstrated paw withdrawal response and paw withdrawal latency patterns indicating recovery from pain, whereas untreated rats continued to have significant pain behavior patterns. The mechanisms underlying this improvement following bone marrow injection are unknown. The authors speculate that the marrow cells functioned as anti-inflammatory, neuroprotective, and proangiogenic, modulating ischemic, inflammatory, and cytotoxic events in the pain that follows nerve constriction in this model. However, marrow transplants are also known to exacerbate diabetic neuropathy in a different model of pain [185]. In this case, marrow cells fused with peripheral neurons, stimulating apoptosis.

One cause of severe neuropathic pain is traumatic injury that involves SCI is spinal root avulsion, and replacement of DRG neurons could reduce that pain. A recent study investigated whether human neural stem/progenitor cells (hNSPCs) transplanted to the DRG cavity can serve as a source for repairing lost peripheral sensory connections [186]. The hNSPCs robustly differentiate to neurons, which survive long-term transplantation. The neuronal population in the transplants was tightly surrounded by astrocytes, suggesting their active role in neuron survival. Furthermore, 3 months after grafting, hNSPCs were found in the dorsal root transitional zone (DRTZ) and within the spinal cord. The level of differentiation of transplanted cells was high in the core of the transplants whereas cells that migrated to the DRTZ and spinal cord were undifferentiated, nestinexpressing precursors. However, hNSPCs are not sufficient to restore normal sensory function; additional factors are required to guide their differentiation to the desired type of neurons.

9.3. Neuroprogenitor Cell Lines for Pain (The NT2 Cell Line). More than two decades ago, it was discovered that, when treated with retinoic acid (RA), a human embryonal carcinoma cell line, NTera2cl.D/l (NT2, hNT2), differentiates irreversibly into several morphologically and phenotypically distinct cell types, which include terminally differentiated 
postmitotic CNS neurons [187, 188]. Successive replating of RA-treated NT2 cells, in the presence of growth inhibitors, results in the isolation of purified human neurons [189], which have been extensively characterized and tested in vivo in a number of animal models of traumatic injury and neurodegenerative disease [188, 190-194]. This NT2 human neural cell line has been used for a variety of studies that reveal not only the regulation of an oncogenic phenotype by agents such as retinoic acid $[189,195,196]$, but it has been well characterized for the expression of a variety of neural phenotypic properties [197] and proteins [198, 199] with differentiation of the cells in vitro and in vivo [200]. The potential application of NT2 neurons in cell transplantation therapy for CNS disorders, and their use as vehicles for delivering exogenous proteins into the human brain for gene therapy, has been envisioned [201]. Such NT2 neurons have been used in Phase I-II clinical trials for the treatment of stroke [202-204], and this cell line or its derivatives can likely be utilized for further reparative transplant strategies [205]. The rate-limiting enzyme GAD, for GABA synthesis is present in differentiating NT2 neurons in vitro [206, 207], and GABA is a phenotype for NT2 cells differentiated and transplanted in vivo [208]. But the NT2 cell line has a great variety of phenotypes expressed in differentiated cells [193, 207], making it less-than-ideal for a specific antinociceptive phenotype expression that might be required for application in pain management, as has been modeled in rat cell lines described above. While induction of a GABAergic phenotype in neural stem cells is possible with a somewhat complicated method of sequential exposure to epigenetic signals in vitro [209], the host graft environment does not always allow for induction of desirable phenotypes in vivo [210]. A naturally occurring, stable antinociceptive phenotype in a clinically useful human progenitor cell line, such as that derived from the NT2 cell line, is more desirable, and these are described below.

9.4. NT2-Derived Cell Lines for Pain. Since the NT2 cell line contains a mixed phenotype population of cells, many of which would likely be antinociceptive based on multiple studies with rat cell lines by this author and others using central and peripheral models of neuropathic pain [110, 111, $113,115-119,170,211]$, it was considered likely that individual cell lines could be subcloned from the NT2 parental cell lines, using ordinary subcloning techniques involving isolation of individual cells plated sparsely, allowing them to grow into colonies, surrounding these with cloning rings, and removing these colonies to establish individual cell lines. This rather laborious process resulted in a number of well-growing, morphologically and immunohistochemically distinct NT2 subclonal cell lines, numbered consecutively as they were isolated. Two of the cell lines were chosen for their potential to function as sources of neurotransmitters which might prove useful in further testing in animal models of pain, the hNT2.17 [212] and hNT2.19 [213] cell lines. Since they are derived from the neuroprogenitor parent cell line NT2, these are considered to be human neuroprogenitor cell lines as well, resulting in a neuronal-limited phenotype, and will be described below. These human progenitor cell lines are being developed for clinical use. Their characterization and use in animal models reflect what will be required of any similar regenerative cell therapy for FDA approval $[98,214]$.

9.5. The Human Neuronal GABA hNT2.17 Cell Line. Centrally induced excitotoxic SCI has been developed as a model of neuropathic pain $[215,216]$. Intraspinal injection of quisqualic acid (QUIS), a mixed AMPA/metabotropic receptor agonist, produces injury with pathological characteristics similar to those associated with ischemic and traumatic SCI [217]. In addition, the pathological changes that this SCI induces, significant mechanical allodynia, and thermal hyperalgesia have been shown to be important behavioral components, without the additional motor dysfunction seen in other SCI models [218]. Each of these sensory behaviors is indicative of altered sensory function and/or pain, similar to that reported after SCI. After spinal transplantation of primary adrenal tissue grafts following QUIS injections, painrelated behaviors, including the hypersensitivity to mechanical stimuli and "excessive grooming" were significantly reduced [219]. Given the related loss of GABA inhibition that seems to accompany SCI and the induction of neuropathic pain [220-222], the excitotoxic SCI model was used to examine the hNT2-derived GABAergic hNT2.17 cell transplant into the lumbar subarachnoid space following injury and the ability of those grafts to reverse behavioral hypersensitivity [212]. These cells cease to express tumor genes, express an exclusively neuronal, GABAergic and glycinergic phenotype, and synthesize, secrete and release GABA and glycine into the extracellular environment with differentiation [212]. Their morphology is similar to the GABA/glycine spinal interneurons found in the dorsal horn sensory laminae [223] and such characteristics are stable in more than 10 years of use in transplant studies. These inhibitory human neurons additionally co-localize GABA and glycine and the vesicular inhibitory amino acid transporter (VIATT, VGAT), especially along the neurite outgrowths in vitro, suggesting that this molecular machinery allows co-release in hNT2.17 cells [224], without the need for a separate glycine transporter. When differentiated hNT2.17 cells are placed two weeks after the QUIS SCI, mechanical allodynia and thermal hyperalgesia are potently and permanently attenuated, with no greater effect when twice the normal transplant dose $(1$ million cells/i.t. injection) is used $[225,226]$, or grafts are placed in the cervical subdural space [226]. Besides transplant dose and graft placement, the immunosuppression regimen and transplant time after SCI were also optimized [226]. The same optimal transplant dose was only moderately effective when placed in chronic SCI, six weeks after SCI, compared to $100 \%$ effectiveness when placed in an acute SCI, 2 weeks after injury. Additionally, maximal graft effectiveness required two weeks of immunosuppression with cyclosporine A (CsA; $10 \mathrm{mg} / \mathrm{Kg}$ ), immediately following transplant. No immunosuppression or less lengthy exposure to CsA provided minimal or no attenuation [226]. The "excessive grooming" behaviors associated with this model were also examined. When excessively grooming rats that had been transplanted with either viable or nonviable hNT2.17 cells and exposed to different immunosuppression regimens were examined for development, resolution, worsening, or no change of 
excessive grooming, a trend toward improvement was associated with viable grafts and at least 1 week of accompanying CsA immunosuppression. When transplant was delayed to 6 weeks, no improvement in excessive grooming was seen. This last finding duplicates what was seen in the QUIS SCI model and graft of antinociceptive adrenal medullary tissue [219], suggesting potent reversal of behavioral hypersensitivity may have a neuroprotective effect on the progression of spinal excitotoxicity associated spinal lesions. We [227], and others [228], have recently reported on the use of hNT2.17 cell therapy in various other models of peripheral and central nervous system damage, including: CCI of the sciatic nerve, streptozotocin-induced diabetic peripheral neuropathy (DPN) pain, and severe contusive SCI. Much as we [229] and others [56] have seen in the CCI peripheral nerve injury model and antinociceptive cell grafts Vaysse and colleagues [228], reported that the decrease in GABA expression in the spinal dorsal horn of CCI injured animals is concomitant with a decline of its synthetic enzyme GAD67 immunoreactivity (ir) and mRNA but not GAD65. In hNT2.17 transplanted animals a strong induction of GAD67 mRNA one week after graft was seen, which was followed by a recovery of GAD67 and GABA ir. This effect paralleled a reduction of hindpaw hypersensitivity and thermal hyperalgesia induced by CCI. These results suggest not only that hNT2.17 GABA cells can modulate neuropathic pain after CCI by minimizing the imbalance and restoring the cellular GABAergic pathway, but that such a mechanism may be associated with any potent antinociceptive cell graft, at least in the CCI model. The same, or a similar mechanism may explain the antinociceptive effects of hNT2.17 grafts in contusive SCI and DPN pain [227]. DPN pain studies have suggested aberrant spinal or supraspinal modulation of sensory processing [230, 231], including a central mechanism [232] with the ventral posterolateral thalamus becoming hyperexcitable in the presence of spinal and supraspinal disinhibition. Disinhibition and loss of spinal GABA modulation are also well reported in SCI pain [222]. But evidence for a GABAergic mechanism associated with hNT2.17 transplant and antinociception in these other models of pain awaits further studies.

9.6. The Human Neuronal 5HT hNT2.19 Cell Line. Current understanding of central and supraspinal [233] mechanisms for the induction and maintenance of chronic pain after SCI suggests a major role for the hypofunction of serotonergic (5HT) inhibitory systems [234-236]. This same SCI leads to the loss of descending serotonergic excitatory inputs caudal to the lesion site and altered neurotransmitter status within the ventral horn a-motoneurons, which also contributes to motor dysfunction after SCI $[116,237]$. A variety of animal studies have used a 5HT rat cell line [110, 116-118] or 5 HT raphe transplants $[238,239]$ as a means to ameliorate some of these problems. Supplemental cell therapy can also work to create a spinal environment to ameliorate local damage and simultaneously promote a regenerative response in multiple axonal populations, including descending spinal serotonin fibers [240], or reverse chronic pain after SCI by reversing the hyperexcitability in the dorsal horn pain processing centers [117]. We have described the use of 5HT cell therapy with a rat $5 \mathrm{HT}$ cell line that is able to permanently reverse neuropathic pain that develops after partial nerve injury [110] and hemisection SCI $[115,241]$. The human neuronal 5HT hNT2.19 cells used for cell therapy after severe contusive SCI reverses behavioral hypersensitivity [241], without affecting motor dysfunction when grafts are placed intrathecally. These same cell grafts modestly recover motor function when placed intraspinally [213] in the same severe contusion SCI model of chronic pain and motor dysfunction. Additionally, grafts of hNT2.19 cells attenuate tactile allodynia and thermal hyperalgesia in the excitotoxic SCI QUIS model [227], much like grafts of hNT2.17 cells. In fact, lumbar intrathecal 5HT hNT2.19 and GABA hNT2.19 grafts are equally nociceptive no matter which SCI pain model is used, excitotoxic or contusive [227], suggesting that these cells may affect the same or similar mechanism-of-action that is common to both models that initiates behavioral hypersensitivity. We have already shown a GABAergic mechanismof-action for grafts of hNT2.17 cells [228] and suggested it may be common in SCI pain. Although grafts of a $5 \mathrm{HT}$ rat neuronal cell line which is antinociceptive after hemisection SCI [116], depending on graft location [115], much like grafts of hNT2.19 cells, it does so by attenuating bilateral hyperexcitability of dorsal horn neurons [117], restores spinal serotonin, downregulates the serotonin transporter, and increases BDNF tissue content in the spinal cord [118], these same 5HT rat cell line grafts also induce a GABAergic mechanism of action in the CCI model of nerve injury and neuropathic pain [229]. Obviously, it will be important in future studies to understand how each separate human neuronal cell line provides antinociception in each PNS or CNS pain model, but the same or similar mechanisms are not out of the question. Since the 5HT hNT2.19 cells, like the hNT2.17 cell line, are exclusively neuronal, although with a different neurotransmitter phenotype, and equally nontumorogenic before and after transplant [227, 241], this human progenitor cell line is equally appropriate to develop as a clinical tool, not only to treat neuropathic pain, but also motor dysfunction, especially after SCI [241-243] (Table 4).

\section{Summary of Advantages and Disadvantages and Future Directions of Cell-Therapy Approaches}

To summarize the conclusions from 30 years of cell therapy studies, the advantages and disadvantages of a cell-based approach to the treatment of neuropathic pain would include the following (1) It is likely that only human cells will be useful as a source, whether primary tissue or cell lines given that such sources are the least likely to be rejected, would function appropriately, and respond to environmental cues in the human host. Encapsulation technologies could be helpful here, if these technologies could keep the grafts both viable and functional. However, (2) it is likely that there are limits to the achievable levels of a given biologic agent that can be delivered by the cells and multiple intrathecal injections over time, with return of pain, may be necessary. (3) It is possible that delivery of a multitude of substances, in addition to 
TABLE 4: Stem/Precursor cell lines.

\begin{tabular}{|c|c|c|}
\hline Source & Model & Results \\
\hline $\begin{array}{l}\text { Stem/Progenitors: } \\
\text { Rat spinal (embryonic) progenitor cells } \\
\text { [184] } \\
\text { Adrenal progenitors_human [281] }\end{array}$ & Partial nerve injury (CCI) [184] & (i) Reduced thermal hyperalgesia [184] \\
\hline $\begin{array}{l}\text { Human neuronal/progenitors: } \\
\text { Human NT2 cell line }[205,282,283]\end{array}$ & Excitotoxic SCI pain [283] & $\begin{array}{l}\text { (i) Release cannabinoids [282] } \\
\text { (ii) Antinociceptive [283] }\end{array}$ \\
\hline $\begin{array}{l}\text { Human NT2.17 GABA cell line } \\
{[212,225,226,228,283,284]}\end{array}$ & $\begin{array}{l}\text { Excitotoxic SCI (QUIS) } \\
{[212,225,226,283-285]} \\
\text { Streptozotocin-induced diabetic } \\
\text { peripheral neuropathy (DPN) [283] } \\
\text { Partial nerve injury (CCI) [228, 283] }\end{array}$ & $\begin{array}{l}\text { (i) Antinociceptive [212, 226, 228, 283] } \\
\text { (ii) Restores spinal GABA DH inhibition [228] } \\
\text { (iii) Colocalize/release GABA and glycine [212] }\end{array}$ \\
\hline $\begin{array}{l}\text { Human NT2.19 5HT cell line } \\
{[213,241,283]}\end{array}$ & $\begin{array}{l}\text { (i) Contusive SCI }[213,241] \\
\text { (ii) Excitotoxic SCI }[283]\end{array}$ & $\begin{array}{l}\text { (i) Intraspinal grafts attenuate motor } \\
\text { dysfunction [213] } \\
\text { (ii) Intrathecal grafts provide antinociception } \\
{[241,283]}\end{array}$ \\
\hline
\end{tabular}

those of therapeutic interest, many of which cannot be completely defined before hand, will be associated with cellbased therapy. Different subgroups of pain patients may respond to such agents in either positive or negative ways dependent on each person's primary cause of pain. Valid and reliable phenotypic classification of pain based on individual signs and symptoms, and various biomarkers, may be helpful in defining such subgroups and their responses to a specific substance related to cell transplant. Such responses are unknown until very large populations are treated with any given cell source. (4) It seems that more acute neuropathic pain is treatable with cell therapy; chronic pain may require multiple i.t. injections as needed. Even still, pain relief may not be equally effective in all cases, and additional pharmacologic and cognitive/adjuvant therapies will be needed. (5) There is a dependence on the survival of implanted cells, which may be limited by immunologic factors, nutrient and oxygen supply, and so forth. However, such survival and efficacy can be tested preclinically, in nonhuman studies. (6) It is likely, at least for now, that only the simplest approaches to creating cell sources will be quickly approved for clinical trials, that is, not overly-manipulated (in cell culture) or bio-engineered cells (containing viral vectors). (7) Some course of immunosuppression will likely be required, even for autologous sources, but such regimens could be tested rigorously in preclinical experiments, that is, nonhuman primates. (8) An intrathecal graft site would likely be the best for cell injections for the treatment of neuropathic pain. Any other transplant type would need to be placed as near to its "site-of-action" as is reasonable, especially if grafted cells are known to not migrate, such as with NT2 cells. (9) If cells are used for antinociception, and placed intrathecally, those that passively secrete inhibitory (or drive inhibitory systems) neurotransmitters would likely work the best, rather than cells that secrete any number of known and unknown agents. (10) Transplant sources need to be tested in as many preclinical peripheral and central models of motor and sensory injury as possible, to avoid later "off-label" use/side-effects in humans. (11) A pragmatic, rather than a purely mechanistic, approach can be used for preclinical work. It is more useful that cell therapy approaches are tested, without necessarily understanding how they work, as long as such technologies are proven as safe as possible. (12) All efforts should be taken to keep patients/provider costs as low as possible, so that cell therapy can be applied almost as readily as pharmacologic treatments. Cell-based research and development will likely be an expensive and complicated solution to treat pain, compared to a purely pharmacologic or mixed-use mechanical-pump/spinal-stimulator delivery approach. (13) The rapid establishment of a Research Ethics Consortium should be established, to be tasked to assemble an interdisciplinary panel of experts who will apply ethical principles to analyze the social merit relative to the economic incentives of this emerging technology [244]. This consortium will evaluate how these novel ethical issues in emerging technologies are addressed under current oversight and regulatory structures and where there may be gaps and need for revised or new public policy approaches.

\section{References}

[1] G. J. Bennett, "Neuropathic pain: new insights, new interventions," Hospital Practice, vol. 33, no. 10, pp. 95-114, 1998.

[2] N. Torrance, B. H. Smith, M. I. Bennett, and A. J. Lee, “The epidemiology of chronic pain of predominantly neuropathic origin. Results from a general population survey," Journal of Pain, vol. 7, no. 4, pp. 281-289, 2006.

[3] D. Bouhassira, M. Lanteri-Minet, N. Attal, B. Laurent, and C. Touboul, "Prevalence of chronic pain with neuropathic characteristics in the general population," Pain, vol. 136, no. 3, pp. 380-387, 2008.

[4] M. Haanpää, N. Attal, M. Backonja et al., "NeuPSIG guidelines on neuropathic pain assessment," Pain, vol. 152, no. 1, pp. 14-27, 2011.

[5] E. R. Felix, Y. Cruz-Almeida, and E. G. Widerstrom-Noga, "Chronic pain after spinal cord injury: what characteristics make some pains more disturbing than others?" Journal of Rehabilitation Research and Development, vol. 44, no. 5, pp. 703-716, 2007.

[6] P. J. Siddall, J. M. McClelland, S. B. Rutkowski, and M. J. Cousins, "A longitudinal study of the prevalence and 
characteristics of pain in the first 5 years following spinal cord injury," Pain, vol. 103, no. 3, pp. 249-257, 2003.

[7] F. Biering-Sorensen, N. B. Finnerup, D. D. Cardenas et al., "International spinal cord injury pain classification: part I. Background and description," Spinal Cord. In press.

[8] E. G. Widerstrom-Noga, E. Felipe-Cuervo, J. G. Broton, R. C. Duncan, and R. P. Yezierski, "Perceived difficulty in dealing with consequences of spinal cord injury," Archives of Physical Medicine and Rehabilitation, vol. 80, no. 5, pp. 580-586, 1999.

[9] Y. Cruz-Almeida, A. Martinez-Arizala, and E. G. Widerstrom-Noga, "Chronicity of pain associated with spinal cord injury: a longitudinal analysis," Journal of Rehabilitation Research and Development, vol. 42, no. 5, pp. 585-594, 2005.

[10] P. J. Siddall, M. J. Cousins, A. Otte, T. Griesing, R. Chambers, and T. K. Murphy, "Pregabalin in central neuropathic pain associated with spinal cord injury: a placebo-controlled trial," Neurology, vol. 67, no. 10, pp. 1792-1800, 2006.

[11] “2011 National Diabetes Fact Sheet,” 2011, http://www.cdc .gov/diabetes/pubs/pdf/ndfs_2011.pdf.

[12] J. R. Mendell and Z. Sahenk, "Painful sensory neuropathy," The New England Journal of Medicine, vol. 348, no. 13, pp. 1243-1255, 2003.

[13] H. Klit, N. B. Finnerup, and T. S. Jensen, "Central poststroke pain: clinical characteristics, pathophysiology, and management," The Lancet Neurology, vol. 8, no. 9, pp. 857868, 2009.

[14] C. J. Vierck, P. T. Hansson, and R. P. Yezierski, "Clinical and pre-clinical pain assessment: are we measuring the same thing?" Pain, vol. 135, no. 1-2, pp. 7-10, 2008.

[15] R. H. Dworkin, A. B. O'Connor, M. Backonja et al., "Pharmacologic management of neuropathic pain: evidence-based recommendations," Pain, vol. 132, no. 3, pp. 237-251, 2007.

[16] N. Attal, G. Cruccu, M. Haanpää et al., "EFNS guidelines on pharmacological treatment of neuropathic pain," European Journal of Neurology, vol. 13, no. 11, pp. 1153-1169, 2006.

[17] D. E. Moulin, A. J. Clark, I. Gilron et al., "Pharmacological management of chronic neuropathic pain-consensus statement and guidelines from the canadian pain society," Pain Research and Management, vol. 12, no. 1, pp. 13-21, 2007.

[18] R. H. Dworkin, A. B. O'Connor, J. Audette et al., "Recommendations for the pharmacological management of neuropathic pain: an overview and literature update," Mayo Clinic Proceedings, vol. 85, no. 3, supplement, pp. S3-S14, 2010.

[19] T. P. Nash, "Treatment options in painful diabetic neuropathy," Acta Neurologica Scandinavica, Supplement, vol. 100, no. 173, pp. 36-42, 1999.

[20] G. Cruccu, T. Z. Aziz, L. Garcia-Larrea et al., "EFNS guidelines on neurostimulation therapy for neuropathic pain," European Journal of Neurology, vol. 14, no. 9, pp. 952-970, 2007.

[21] C. Norrbrink Budh and T. Lundeberg, "Non-pharmacological pain-relieving therapies in individuals with spinal cord injury: a patient perspective," Complementary Therapies in Medicine, vol. 12, no. 4, pp. 189-197, 2004.

[22] H. Merskey and N. Bogduk, Classification of Chronic Pain: Descriptions of Chronic Syndromes and Definitions of Pain Terms, IASP Press, Seattle, Wash, USA, 2nd edition, 1994.

[23] R. D. Treede, T. S. Jensen, J. N. Campbell et al., "Neuropathic pain: redefinition and a grading system for clinical and research purposes," Neurology, vol. 70, no. 18, pp. 1630-1635, 2008.

[24] T. S. Jensen, R. Baron, M. Haanpää et al., "A new definition of neuropathic pain,” Pain, vol. 152, no. 10, pp. 2204-2205, 2011.
[25] N. B. Finnerup, L. Sorensen, F. Biering-Sorensen, I. L. Johannesen, and T. S. Jensen, "Segmental hypersensitivity and spinothalamic function in spinal cord injury pain," Experimental Neurology, vol. 207, no. 1, pp. 139-149, 2007.

[26] C. J. Woolf and M. B. Max, "Mechanism-based pain diagnosis: issues for analgesic drug development," Anesthesiology, vol. 95, no. 1, pp. 241-249, 2001.

[27] T. W. Victor, M. P. Jensen, A. R. Gammaitoni, E. M. Gould, R. E. White, and B. S. Galer, "The dimensions of pain quality: factor analysis of the pain quality assessment scale," Clinical Journal of Pain, vol. 24, no. 6, pp. 550-555, 2008.

[28] R. H. Dworkin, M. P. Jensen, A. R. Gammaitoni, D. O. Olaleye, and B. S. Galer, "Symptom profiles differ in patients with neuropathic versus non-neuropathic pain," Journal of Pain, vol. 8, no. 2, pp. 118-126, 2007.

[29] R. Rolke, W. Magerl, K. A. Campbell et al., "Quantitative sensory testing: a comprehensive protocol for clinical trials," European Journal of Pain, vol. 10, no. 1, pp. 77-88, 2006.

[30] C. Maier, R. Baron, T. R. Tolle et al., "Quantitative sensory testing in the German research network on neuropathic pain (DFNS): somatosensory abnormalities in 1236 patients with different neuropathic pain syndromes," Pain, vol. 150, no. 3, pp. 439-450, 2010.

[31] P. J. Siddall and M. J. Cousins, "Spine update: spinal pain mechanisms,” Spine, vol. 22, no. 1, pp. 98-104, 1997.

[32] J. Sagen and J. E. Kemmler, "Increased levels of met-enkephalin-like immunoreactivity in the spinal cord CSF of rats with adrenal medullary transplants," Brain Research, vol. 502, no. 1, pp. 1-10, 1989.

[33] B. G. Livett, D. M. Dean, L. G. Whelan et al., "Co-release of enkephalin and catecholamines from cultured adrenal chromaffin cells," Nature, vol. 289, no. 5795, pp. 317-319, 1981.

[34] B. G. Livett, P. Boksa, D. M. Dean et al., "Use of isolated chromaffin cells to study basic release mechanisms," Journal of the Autonomic Nervous System, vol. 7, no. 1, pp. 59-86, 1983.

[35] J. Sagen, G. D. Pappas, and H. B. Pollard, "Analgesia induced by isolated bovine chromaffin cells implanted in rat spinal cord," Proceedings of the National Academy of Sciences of the United States of America, vol. 83, no. 19, pp. 7522-7526, 1986.

[36] J. Sagen, G. D. Pappas, and M. J. Perlow, "Adrenal medullary tissue transplants in the rat spinal cord reduce pain sensitivity," Brain Research, vol. 384, no. 1, pp. 189-194, 1986.

[37] J. I. Ruz-Franzi and J. M. González-Darder, "Study of the analgesic effects of the implant of adrenal medullary into the subarachnoid space in rats," Acta Neurochirurgica, Supplement, vol. 52, pp. 39-41, 1991.

[38] J. Sagen, G. D. Pappas, and M. J. Perlow, "Alterations in nociception following adrenal medullary transplants into the rat periaqueductal gray," Experimental Brain Research, vol. 67, no. 2, pp. 373-379, 1987.

[39] J. Sagen, H. Wang, and G. D. Pappas, "Adrenal medullary implants in the rat spinal cord reduce nociception in a chronic pain model," Pain, vol. 42, no. 1, pp. 69-79, 1990.

[40] R. Ginzburg and Z. Seltzer, "Subarachnoid spinal cord transplantation of adrenal medulla suppresses chronic neuropathic pain behavior in rats," Brain Research, vol. 523, no. 1, pp. 147-150, 1990.

[41] J. Sagen, "Chromaffin cell transplants for alleviation of chronic pain," ASAIO Journal, vol. 38, no. 1, pp. 24-28, 1992.

[42] A. T. Hama and J. Sagen, "Reduced pain-related behavior by adrenal medullary transplants in rats with experimental painful peripheral neuropathy," Pain, vol. 52, no. 2, pp. 223231, 1993. 
[43] Y. Lazorthes, B. Sallerin, J. C. Verdie et al., "Management of intractable cancer pain: from intrathecal morphine to chromaffin cell allograft," Neurochirurgie, vol. 46, no. 5, pp. 454-465, 2000.

[44] J. D. Ortega, J. Sagen, and G. D. Pappas, "Short-term immunosuppression enhances long-term survival of bovine chromaffin cell xenografts in rat CNS," Cell Transplantation, vol. 1, no. 1, pp. 33-41, 1992.

[45] J. Sagen, G. D. Pappas, and A. P. Winnie, "Alleviation of pain in cancer patients by adrenal medullary transplants in the spinal subarachnoid space," Cell Transplantation, vol. 2, no. 3, pp. 259-266, 1993.

[46] A. P. Winnie, G. D. Pappas, T. K. D. Gupta, H. Wang, J. D. Ortega, and J. Sagen, "Subarachnoid adrenal medullary transplants for terminal cancer pain: a report of preliminary studies," Anesthesiology, vol. 79, no. 4, pp. 644-653, 1993.

[47] S. P. Wilson, K. J. Chang, and O. H. Viveros, "Opioid peptide synthesis in bovine and human adrenal chromaffin cells," Peptides, vol. 2, supplement 1, pp. 83-88, 1981.

[48] K. Unsicker, "The trophic cocktail made by adrenal chromaffin cells," Experimental Neurology, vol. 123, no. 2, pp. 167173, 1993.

[49] J. B. Siegan and J. Sagen, "Attenuation of formalin pain responses in the rat by adrenal medullary transplants in the spinal subarachnoid space," Pain, vol. 70, no. 2-3, pp. 279285, 1997.

[50] J. Sagen, J. E. Kemmler, and H. Wang, "Adrenal medullary transplants increase spinal cord cerebrospinal fluid catecholamine levels and reduce pain sensitivity," Journal of Neurochemistry, vol. 56, no. 2, pp. 623-627, 1991.

[51] H. Wang and J. Sagen, "Absence of appreciable tolerance and morphine cross-tolerance in rats with adrenal medullary transplants in the spinal cord," Neuropharmacology, vol. 33, no. 5, pp. 681-692, 1994.

[52] A. T. Hama and J. Sagen, "Induction of spinal NADPHdiaphorase by nerve injury is attenuated by adrenal medullary transplants," Brain Research, vol. 640, no. 1-2, pp. 345351, 1994.

[53] J. B. Siegan, A. T. Hama, and J. Sagen, "Alterations in rat spinal cord cGMP by peripheral nerve injury and adrenal medullary transplantation," Neuroscience Letters, vol. 215, no. 1, pp. 49-52, 1996.

[54] J. Sagen and H. Wang, "Adrenal medullary grafts suppress cfos induction in spinal neurons of arthritic rats," Neuroscience Letters, vol. 192, no. 3, pp. 181-184, 1995.

[55] J. B. Siegan and J. Sagen, "Attenuation of NMDA-induced spinal hypersensitivity by adrenal medullary transplants," Brain Research, vol. 680, no. 1-2, pp. 88-98, 1995.

[56] T. Ibuki, A. T. Hama, X. T. Wang, G. D. Pappas, and J. Sagen, "Loss of GABA-immunoreactivity in the spinal dorsal horn of rats with peripheral nerve injury and promotion of recovery by adrenal medullary grafts," Neuroscience, vol. 76, no. 3, pp. 845-858, 1996.

[57] J. B. Siegan, U. Herzberg, B. R. Frydel, and J. Sagen, "Adrenal medullary transplants reduce formalin-evoked cfos expression in the rat spinal cord," Brain Research, vol. 944, no. 1-2, pp. 174-183, 2002.

[58] I. D. Hentall, B. R. Noga, and J. Sagen, "Spinal allografts of adrenal medulla block nociceptive facilitation in the dorsal horn," Journal of Neurophysiology, vol. 85, no. 4, pp. 17881792, 2001.

[59] J. Sagen, H. Wang, P. A. Tresco, and P. Aebischer, "Transplants of immunologically isolated xenogeneic chromaffin cells provide a long-term source of pain-reducing neuroactive substances," Journal of Neuroscience, vol. 13, no. 6, pp. 24152423, 1993.

[60] E. Buchser, M. Goddard, B. Heyd et al., "Immunoisolated xenogeneic chromaffin cell therapy for chronic pain: initial clinical experience," Anesthesiology, vol. 85, pp. 1005-1012, 1996.

[61] J. Sagen, "Chromaffin cell transplants in the CNS: basic and clinical update," in Yearbook of Cell and Tissue Transplantation, R. P. Lanza and W. L. Chick, Eds., pp. 71-89, Kluwer Academic, Dodrecht, The Netherlands, 1996.

[62] G. D. Pappas, Y. Lazorthes, J. C. Bes, M. Tafani, and A. P. Winnie, "Relief of intractable cancer pain by human chromaffin cell transplants: experience at two medical centers," Neurological Research, vol. 19, no. 1, pp. 71-77, 1997.

[63] J. Tkaczuk, J. C. Bes, H. Duplan et al., "Intrathecal grafting of unencapsulated adrenal medullary tissue can bring CD4 T lymphocytes into CSF: a potentially deleterious event for the graft," Cell Transplantation, vol. 9, no. 1, pp. 79-91, 2000.

[64] N. Bhattacharya, M. K. Chhetri, K. L. Mukherjee et al., "Human fetal adrenal transplant: a possible role in relieving intractable pain in advanced rheumatoid arthiritis," Clinical and Experimental Obstetrics and Gynecology, vol. 29, no. 3, pp. 197-206, 2002.

[65] Y. Jeon, W. Y. Baek, S. H. Chung, N. Shin, H. R. Kim, and S. A. Lee, "Cultured human chromaffin cells grafted in spinal subarachnoid space relieves allodynia in a pain rat model," Korean Journal of Anesthesiology, vol. 60, no. 5, pp. 357-361, 2011.

[66] J. C. Bes, B. R. Frydel, E. D. Potter et al., "Human embryonic and fetal adrenal glands as sources of neural precursors for possible transplantation strategies," American Society for Neural Transplantation and Repair, vol. 8, article 61, 2001.

[67] S. Jozan, J. Aziza, S. Châtelin et al., "Human fetal chromaffin cells: a potential tool for cell pain therapy," Experimental Neurology, vol. 205, no. 2, pp. 525-535, 2007.

[68] P. Michalewicz, C. E. Laurito, G. D. Pappas, Y. Lu, and D. C. Yeomans, "Purification of adrenal chromaffin cells increases antinociceptive efficacy of xenotransplants without immunosuppression," Cell Transplantation, vol. 8, no. 1, pp. 103-109, 1999.

[69] S. Mercadante, G. Intravaia, P. Villari et al., "Intrathecal treatment in cancer patients unresponsive to multiple trials of systemic opioids," Clinical Journal of Pain, vol. 23, no. 9, pp. 793-798, 2007.

[70] J. C. Bes, Y. Lazorthes, J. C. Sol, J. Tkaczuk, and B. Sallerin, "Clinical perspectives of xenografts: encapsuled chromaffin cells and pain," Pathologie Biologie, vol. 48, no. 4, pp. 365$367,2000$.

[71] Y. Lazorthes, J. Sagen, B. Sallerin et al., "Human chromaffin cell graft into the CSF for cancer pain management: a prospective phase II clinical study," Pain, vol. 87, no. 1, pp. 1932,2000

[72] J. C. Bes, J. Tkaczuk, K. A. Czech et al., “One-year chromaffin cell allograft survival in cancer patients with chronic pain: morphological and functional evidence," Cell Transplantation, vol. 7, no. 3, pp. 227-238, 1998.

[73] Y. Lazorthes, J. C. Bes, J. Sagen et al., "Transplantation of human chromaffin cells for control of intractable cancer pain," Acta Neurochirurgica, Supplement, vol. 64, pp. 97-100, 1995.

[74] L. A. Greene and A. S. Tischler, "Establishment of a noradrenergic clonal line of rat adrenal pheochromocytoma cells which respond to nerve growth factor," Proceedings of the National Academy of Sciences of the United States of America, vol. 73, no. 7, pp. 2424-2428, 1976. 
[75] S. Gajavelli, D. A. Castellanos, O. Furmanski, P. C. Schiller, and J. Sagen, "Sustained analgesic peptide secretion and cell labeling using a novel genetic modification," Cell Transplantation, vol. 17, no. 4, pp. 445-455, 2008.

[76] J. B. Siegan and J. Sagen, "A natural peptide with NMDA inhibitory activity reduces tonic pain in the formalin model," NeuroReport, vol. 8, no. 6, pp. 1379-1381, 1997.

[77] F. NasiriNezhad and J. Sagen, "NMDA antagonist peptide supplementation enhances pain alleviation by adrenal medullary transplants," Cell Transplantation, vol. 14, no. 4, pp. 203-211, 2005.

[78] J. C. Byrd, M. Hadjiconstantinou, and D. Cavalla, "Epinephrine synthesis in the PC12 pheochromocytoma cell line," European Journal of Pharmacology, vol. 127, no. 1-2, pp. 139$142,1986$.

[79] M. Yoshikawa, H. Nakayama, S. Ueno, M. Hirano, H. Hatanaka, and H. Furuya, "Chronic fentanyl treatments induce the up-regulation of $\mu$ opioid receptor mRNA in rat pheochromocytoma cells," Brain Research, vol. 859, no. 2, pp. 217-223, 2000.

[80] T. L. Stockley and P. L. Chang, "Non-autologous transplantation with immuno-isolation in large animals-a review," Annals of the New York Academy of Sciences, vol. 831, pp. 408426, 1997.

[81] H. H. Wu, B. R. Lester, Z. Sun, and G. L. Wilcox, "Antinociception following implantation of mouse B16 melanoma cells in mouse and rat spinal cord," Pain, vol. 56, no. 2, pp. 203-210, 1994.

[82] V. Curto-Reyes, L. Juárez, E. García-Pérez et al., "Local loperamide inhibits thermal hyperalgesia but not mechanical allodynia induced by intratibial inoculation of melanoma cells in mice," Cellular and Molecular Neurobiology, vol. 28, no. 7, pp. 981-990, 2008.

[83] J. L. de la Calle, M. A. Mena, J. R. Gonzaez-Escalada, and C. L. Paíno, "Intrathecal transplantation of neuroblastoma cells decreases heat hyperalgesia and cold allodynia in a rat model of neuropathic pain," Brain Research Bulletin, vol. 59, no. 3, pp. 205-211, 2002.

[84] H. H. Wu, G. L. Wilcox, and S. C. McLoon, "Implantation of AtT-20 or genetically modified AtT-20/hENK cells in mouse spinal cord induced antinociception and opioid tolerance," Journal of Neuroscience, vol. 14, no. 8, pp. 4806-4814, 1994.

[85] Y. Saitoh, T. Taki, N. Arita, T. Ohnishi, and T. Hayakawa, "Analgesia induced by transplantation of encapsulated tumor cells secreting $\beta$-endorphin," Journal of Neurosurgery, vol. 82, no. 4, pp. 630-634, 1995.

[86] Y. Saitoh, Y. Eguchi, Y. Hagihara et al., "Dose-dependent doxycycline-mediated adrenocorticotropic hormone secretion from encapsulated Tet-on proopiomelanocortin Neuro2A cells in the subarachnoid space," Human Gene Therapy, vol. 9, no. 7, pp. 997-1002, 1998.

[87] K. Ishii, M. Isono, R. Inoue, and S. Hori, "Attempted gene therapy for intractable pain: dexamethasone-mediated exogenous control of $\beta$-endorphin secretion in genetically modified cells and intrathecal transplantation," Experimental Neurology, vol. 166, no. 1, pp. 90-98, 2000.

[88] Y. Saitoh, T. Taki, N. Arita, T. Ohnishi, and T. Hayakawa, "Cell therapy with encapsulated xenogeneic tumor cells secreting $\beta$-endorphin for treatment of peripheral pain," Cell Transplantation, vol. 4, supplement 1, pp. S13-S17, 1995.

[89] H. Hodges, K. Pollock, P. Stroemer et al., "Making stem cell lines suitable for transplantation," Cell Transplantation, vol. 16, no. 2, pp. 101-115, 2007.

[90] W. Chen, R. Mi, N. Haughey, M. Oz, and A. Hoke, "Immortalization and characterization of a nociceptive dorsal root ganglion sensory neuronal line," Journal of the Peripheral Nervous System, vol. 12, no. 2, pp. 121-130, 2007.

[91] Q. Gökhan, Q. Song, and M. F. Mehler, "Generation and regulation of developing immortalized neural cell lines," Methods, vol. 16, no. 3, pp. 345-358, 1998.

[92] U. Lendahl and R. D. G. McKay, "The use of cell lines in neurobiology," Trends in Neurosciences, vol. 13, no. 4, pp. 132-137, 1990.

[93] C. L. Cepko, "Immortalization of neural cells via retrovirusmediated oncogene transduction," Annual Review of Neuroscience, vol. 12, pp. 47-65, 1989.

[94] P. S. Jat and P. A. Sharp, "Cell lines established by a temperature-sensitive simian virus 40 large-T-antigen gene are growth restricted at the nonpermissive temperature," Molecular and Cellular Biology, vol. 9, no. 4, pp. 1672-1681, 1989.

[95] P. S. Jat, M. D. Noble, P. Ataliotis et al., "Direct derivation of conditionally immortal cell lines from an $\mathrm{H}-2 \mathrm{~K}^{\mathrm{b}}$-tsA58 transgenic mouse," Proceedings of the National Academy of Sciences of the United States of America, vol. 88, no. 12, pp. 5096-5100, 1991.

[96] J. Y. Jiang, B. G. Lyeth, G. L. Clifton, L. W. Jenkins, R. J. Hamm, and R. L. Hayes, "Relationship between body and brain temperature in traumatically brain-injured rodents," Journal of Neurosurgery, vol. 74, no. 3, pp. 492-496, 1991.

[97] T. M. S. Chang and S. Prakash, "Therapeutic uses of microencapsulated genetically engineered cells," Molecular Medicine Today, vol. 4, no. 5, pp. 221-227, 1998.

[98] H. Isaac Chen, A. Bakshi, N. C. Royo, S. N. Magge, and D. J. Watson, "Neural stem cells as biological minipumps: a faster route to cell therapy for the CNS?" Current Stem Cell Research and Therapy, vol. 2, no. 1, pp. 13-22, 2007.

[99] F. H. Gage, J. A. Wolff, M. B. Rosenberg et al., "Grafting genetically modified cells to the brain: possibilities for the future," Neuroscience, vol. 23, no. 3, pp. 795-807, 1987.

[100] A. D. Zurn, J. Tseng, and P. Aebischer, "Treatment of Parkinson's disease. Symptomatic cell therapies: cells as biological minipumps," European neurology, vol. 36, no. 6, pp. 405-408, 1996.

[101] J. Sagen and M. J. Eaton, "Cellular implantation for the treatment of chronic pain," in Pain: Current Understanding, Emerging Therapies, and Novel Approaches to Drug Discovery, W. K. Schmidt, Ed., pp. 815-833, Marcel Dekker, New York, NY, USA, 2003.

[102] L. A. White, M. J. Eaton, M. C. Castro et al., "Distinct regulatory pathways control neurofilament expression and neurotransmitter synthesis in immortalized serotonergic neurons," Journal of Neuroscience, vol. 14, no. 11 I, pp. 6744-6753, 1994.

[103] S. R. Whittemore and L. A. White, "Target regulation of neuronal differentiation in a temperature-sensitive cell line derived from medullary raphe," Brain Research, vol. 615, no. 1, pp. 27-40, 1993.

[104] M. J. Eaton, J. K. Staley, M. Y. Y. Globus, and S. R. Whittemore, "Developmental regulation of early serotonergic neuronal differentiation: the role of brain-derived neurotrophic factor and membrane depolarization," Developmental Biology, vol. 170, no. 1, pp. 169-182, 1995.

[105] J. S. Rudge, M. J. Eaton, P. Mather, R. M. Lindsay, and S. R. Whittemore, "CNTF induces raphe neuronal precursors to switch from a serotonergic to a cholinergic phenotype in vitro," Molecular and Cellular Neurosciences, vol. 7, no. 3, pp. 204-221, 1996.

[106] M. J. Eaton, H. A. Dancausse, and S. R. Whittemore, "GDNF and neurturin affect the survival and 5HT synthesis in immortalized raphe neuronal precursors," in Proceedings of the Summer Neuropeptide Conference, 1997. 
[107] M. J. Eaton and S. R. Whittemore, "Adrenocorticotropic hormone activation of adenylate cyclase in raphe neurons: multiple regulatory pathways control serotonergic neuronal differentiation," Journal of Neurobiology, vol. 28, no. 4, pp. 465481, 1995.

[108] M. J. Eaton and S. R. Whittemore, "Autocrine BDNF secretion enhances the survival and serotonergic differentiation of raphe neuronal precursor cells grafted into the adult rat CNS," Experimental Neurology, vol. 140, no. 2, pp. 105-114, 1996.

[109] A. E. Farakash and R. K. Portney, "The pharmacological management of chronic pain in the paraplegic patient," The Journal of the American Paraplegia Society, vol. 9, pp. 41-50, 1986.

[110] M. J. Eaton, H. A. Dancausse, D. I. Santiago, and S. R. Whittemore, "Lumbar transplants of immortalized serotonergic neurons alleviate chronic neuropathic pain," Pain, vol. 72, no. 1-2, pp. 59-69, 1997.

[111] M. J. Eaton, S. Karmally, M. A. Martinez, J. A. Plunkett, T. Lopez, and P. J. Cejas, "Lumbar transplant of neurons genetically modified to secrete galanin reverse pain-like behaviors after partial sciatic nerve injury," Journal of the Peripheral Nervous System, vol. 4, no. 3-4, pp. 245-257, 1999.

[112] P. Cejas, J. A. Plunkett, M. A. Martinez et al., "A BDNFsynthesizing cell line ameliorates chronic neuropathic pain," Society for Neuroscience, vol. 25, article 1945, 1999.

[113] M. J. Eaton, J. A. Plunkett, M. A. Martinez et al., “Transplants of neuronal cells bioengineered to synthesize GABA alleviate chronic neuropathic pain," Cell Transplantation, vol. 8, no. 1, pp. 87-101, 1999.

[114] M. J. Eaton, "SCI pain is a GABA-sensitive phenomenon amendable to GABA cell therapy," in Proceedings of the 7th International Conference on the Mechanisms and Treatment of Neuropathic Pain, 2004.

[115] B. C. Hains, J. A. Yucra, M. J. Eaton, and C. E. Hulsebosch, "Intralesion transplantation of serotonergic precursors enhances locomotor recovery but has no effect on development of chronic central pain following hemisection injury in rats," Neuroscience Letters, vol. 324, no. 3, pp. 222226, 2002.

[116] B. C. Hains, K. M. Johnson, D. J. McAdoo, M. J. Eaton, and C. E. Hulsebosch, "Engraftment of serotonergic precursors enhances locomotor function and attenuates chronic central pain behavior following spinal hemisection injury in the rat," Experimental Neurology, vol. 171, no. 2, pp. 361-378, 2001.

[117] B. C. Hains, K. M. Johnson, M. J. Eaton, W. D. Willis, and C. E. Hulsebosch, "Serotonergic neural precursor cell grafts attenuate bilateral hyperexcitability of dorsal horn neurons after spinal hemisection in rat," Neuroscience, vol. 116, no. 4, pp. 1097-1110, 2003.

[118] B. C. Hains, S. D. Fullwood, M. J. Eaton, and C. E. Hulsebosch, "Subdural engraftment of serotonergic neurons following spinal hemisection restores spinal serotonin, downregulates serotonin transporter, and increases BDNF tissue content in rat," Brain Research, vol. 913, no. 1, pp. 35-46, 2001.

[119] L. A. Stubley, M. A. Martinez, S. Karmally, T. Lopez, P. Cejas, and M. J. Eaton, "Only early intervention with gammaaminobutyric acid cell therapy is able to reverse neuropathic pain after partial nerve injury," Journal of Neurotrauma, vol. 18, no. 4, pp. 471-477, 2001.

[120] K. K. Jha, S. Banga, V. Palejwala, and H. L. Ozer, "SV40mediated immortalization," Experimental Cell Research, vol. 245, no. 1, pp. 1-7, 1998.
[121] K. H. Scheidtmann, "SV40 large T antigen induces a protein kinase responsible for phosphorylation of the cellular protein p53," Current Topics in Microbiology and Immunology, vol. 144, pp. 85-88, 1989.

[122] T. L. Sladek and J. W. Jacobberger, "Simian virus 40 large Tantigen expression decreases the G1 and increases the G2+ M cell cycle phase durations in exponentially growing cells," Journal of Virology, vol. 66, no. 2, pp. 1059-1065, 1992.

[123] V. Cherington, M. Brown, E. Paucha, J. St Louis, B. M. Spiegelman, and T. M. Roberts, "Separation of simian virus 40 large-T-antigen-transforming and origin-binding functions from the ability to block differentiation," Molecular and Cellular Biology, vol. 8, no. 3, pp. 1380-1384, 1988.

[124] K. Frederiksen, P. S. Jat, N. Valtz, D. Levy, and R. McKay, "Immortalization of precursor cells from the mammalian CNS," Neuron, vol. 1, no. 6, pp. 439-448, 1988.

[125] Z. Ikram, T. Norton, and P. S. Jat, "The biological clock that measures the mitotic life-span of mouse embryo fibroblasts continues to function in the presence of simian virus 40 large tumor antigen," Proceedings of the National Academy of Sciences of the United States of America, vol. 91, no. 14, pp. 6448-6452, 1994.

[126] I. Reynisdottir, D. R. O’Reilly, L. K. Miller, and C. Prives, "Thermally inactivated simian virus 40 tsA58 mutant T antigen cannot initiate viral DNA replication in vitro," Journal of Virology, vol. 64, no. 12, pp. 6234-6245, 1990.

[127] P. S. Frisa, M. N. Goodman, G. M. Smith, J. Silver, and J. W. Jacobberger, "Immortalization of immature and mature mouse astrocytes with SV40 T antigen," Journal of Neuroscience Research, vol. 39, no. 1, pp. 47-56, 1994.

[128] M. N. Goodman, J. Silver, and J. W. Jacobberger, "Establishment and neurite outgrowth properties of neonatal and adult rat olfactory bulb glial cell lines," Brain Research, vol. 619, no. 1-2, pp. 199-213, 1993.

[129] P. S. Jat and P. A. Sharp, "Large T antigens of simian virus 40 and polyomavirus efficiently establish primary fibroblasts," Journal of Virology, vol. 59, no. 3, pp. 746-750, 1986.

[130] K. N. Prasad, E. D. Clarkson, F. G. La Rosa, J. EdwardsPrasad, and C. R. Freed, "Efficacy of grafted immortalized dopamine neurons in an animal model of parkinsonism: a review," Molecular Genetics and Metabolism, vol. 65, no. 1, pp. $1-9,1998$.

[131] D. E. Bredesen, K. Hisanaga, and F. R. Sharp, "Neural transplantation using temperature-sensitive immortalized neural cells: a preliminary report," Annals of Neurology, vol. 27, no. 2, pp. 205-207, 1990.

[132] P. J. Renfranz, M. G. Cunningham, and R. D. G. McKay, "Region-specific differentiation of the hippocampal stem cell line HiB5 upon implantation into the developing mammalian brain," Cell, vol. 66, no. 4, pp. 713-729, 1991.

[133] S. R. Whittemore, V. R. Holets, R. W. Keane, D. J. Levy, and R. D. G. McKay, "Transplantation of a temperature-sensitive, nerve growth factor-secreting, neuroblastoma cell line into adult rats with fimbria-fornix lesions rescues cholinergic septal neurons," Journal of Neuroscience Research, vol. 28, no. 2, pp. 156-170, 1991.

[134] S. M. Onifer, S. R. Whittemore, and V. R. Holets, "Variable morphological differentiation of a raphe-derived neuronal cell line following transplantation into the adult rat CNS," Experimental Neurology, vol. 122, no. 1, pp. 130-142, 1993.

[135] L. S. Shihabuddin, J. A. Hertz, V. R. Holets, and S. R. Whittemore, "The adult CNS retains the potential to direct region-specific differentiation of a transplanted neuronal precursor cell line," Journal of Neuroscience, vol. 15, no. 10, pp. 6666-6678, 1995. 
[136] L. S. Shihabuddin, J. P. Brunschwig, V. R. Holets, M. B. Bunge, and S. R. Whittemore, "Induction of mature neuronal properties in immortalized neuronal precursor cells following grafting into the neonatal CNS," Journal of Neurocytology, vol. 25, no. 2, pp. 101-111, 1996.

[137] L. S. Shihabuddin, V. R. Holets, and S. R. Whittemore, "Selective hippocampal lesions differentially affect the phenotypic fate of transplanted neuronal precursor cells," Experimental Neurology, vol. 139, no. 1, pp. 61-72, 1996.

[138] M. J. Eaton, B. Frydel, T. Lopez et al., "Generation and initial characterization of conditionally immortalized chromaffin cells," Journal of Cellular Biochemistry, vol. 79, pp. 38-57, 2000.

[139] M. J. Eaton, M. Martinez, S. Karmally, T. Lopez, and J. Sagen, "Initial characterization of the transplant of immortalized chromaffin cells for the attenuation of chronic neuropathic pain," Cell Transplantation, vol. 9, no. 5, pp. 637-656, 2000.

[140] K. Unsicker, "The chromaffin cell: paradigm in cell, developmental and growth factor biology," Journal of Anatomy, vol. 183, no. 2, pp. 207-221, 1993.

[141] M. Livett, S. Spector, A. Sjoerdsma et al., "Elucidation of the rate-limiting step in norepinephrine biosynthesis in the perfused guinea-pig heart," Journal of Pharmacology and Experimental Therapeutics, vol. 148, pp. 1-8, 1965.

[142] V. M. Pickel, T. Hyub Joh, P. M. Field et al., "Cellular localization of tyrosine hydroxylase by immunohistochemistry," Journal of Histochemistry and Cytochemistry, vol. 23, no. 1, pp. 1-12, 1975.

[143] I. Totzauer, W. Amselgruber, F. Sinowatz, and M. Gratzl, "Early expression of chromogranin A and tyrosine hydroxylase during prenatal development of the bovine adrenal gland," Anatomy and Embryology, vol. 191, no. 2, pp. 139143, 1995.

[144] K. A. Czech, R. Pollak, G. D. Pappas, and J. Sagen, "Bovine chromaffin cells for CNS transplantation do not elicit xenogeneic T cell proliferative responses in vitro," Cell Transplantation, vol. 5, no. 2, pp. 257-267, 1996.

[145] A. A. J. Verhofstad, "Kinetics of adrenal medullary cells," Journal of Anatomy, vol. 183, no. 2, pp. 315-326, 1993.

[146] B. G. Livett, "Adrenal medullary chromaffin cells in vitro," Physiological Reviews, vol. 64, no. 4, pp. 1103-1161, 1984.

[147] K. Anastassiadis, M. Rostovskaya, S. Lubitz, S. Weidlich, and A. F. Stewart, "Precise conditional immortalization of mouse cells using tetracycline-regulated SV40 large Tantigen," Genesis, vol. 48, no. 4, pp. 220-232, 2010.

[148] M. J. Eaton and H. Duplan, "Useful cell lines derived from the adrenal medulla," Molecular and Cellular Endocrinology, vol. 228, no. 1-2, pp. 39-52, 2004.

[149] B. Sauer and N. Henderson, "Site-specific DNA recombination in mammalian cells by the Cre recombinase of bacteriophage P1," Proceedings of the National Academy of Sciences of the United States of America, vol. 85, no. 14, pp. 5166-5170, 1988.

[150] B. Sauer, "Inducible gene targeting in mice using the Cre/lox system," Methods, vol. 14, no. 4, pp. 381-392, 1998.

[151] F. Paillard, "Reversible cell immortalization with the Cre-lox system," Human Gene Therapy, vol. 10, no. 10, pp. 1597$1598,1999$.

[152] K. A. Westerman and P. Leboulch, "Reversible immortalization of mammalian cells mediated by retroviral transfer and site-specific recombination," Proceedings of the National Academy of Sciences of the United States of America, vol. 93, no. 17, pp. 8971-8976, 1996.

[153] N. Kobayashi, M. Miyazaki, K. Fukaya et al., "Treatment of surgically induced acute liver failure with transplantation of highly differentiated immortalized human hepatocytes," Cell Transplantation, vol. 9, no. 5, pp. 733-735, 2000.

[154] A. Weber, "Immortalization of hepatic progenitor cells," Pathologie Biologie, vol. 52, no. 2, pp. 93-96, 2004.

[155] D. Metzger and R. Feil, "Engineering the mouse genome by site-specific recombination," Current Opinion in Biotechnology, vol. 10, no. 5, pp. 470-476, 1999.

[156] C. Kellendonk, F. Tronche, A. P. Monaghan, P. O. Angrand, F. Stewart, and G. Schütz, "Regulation of Cre recombinase activity by the synthetic steroid RU 486," Nucleic Acids Research, vol. 24, no. 8, pp. 1404-1411, 1996.

[157] C. Kellendonk, F. Tronche, E. Casanova, K. Anlag, C. Opherk, and G. Schütz, "Inducible site-specific recombination in the brain," Journal of Molecular Biology, vol. 285, no. 1, pp. 175182, 1999.

[158] M. J. Eaton, J. P. Herman, N. Jullien, T. L. Lopez, M. Martinez, and J. Huang, "Immortalized chromaffin cells disimmortalized with Cre/lox site-directed recombination for use in cell therapy for pain after partial nerve injury," Experimental Neurology, vol. 175, no. 1, pp. 49-60, 2002.

[159] Y. X. Jiang, Y. Lu, T. J. Liu, J. Yang, Y. Chen, and Y. W. Fang, "Using HSV-TK/GCV suicide gene therapy to inhibit lens epithelial cell proliferation for treatment of posterior capsular opacification," Molecular Vision, vol. 17, pp. 291299, 2011.

[160] J. Cai, M. Ito, K. A. Westerman, N. Kobayashi, P. Leboulch, and I. J. Fox, "Construction of a non-tumorigenic rat hepatocyte cell line for transplantation: reversal of hepatocyte immortalization by site-specific excision of the SV40 T antigen," Journal of Hepatology, vol. 33, no. 5, pp. 701-708, 2000.

[161] N. Kobayashi, T. Fujiwara, K. A. Westerman et al., "Prevention of acute liver failure in rats with reversibly immortalized human hepatocytes," Science, vol. 287, no. 5456, pp. 1258 1262,2000

[162] J. P. Herman, H. Becq, and A. Enjalbert, "A reversible immortalization procedure to obtain neural cell lines," Society for Neuroscience, vol. 23, article 319, 1997.

[163] L. Berghella, L. De Angelis, M. Coletta et al., "Reversible immortalization of human myogenic cells by site-specific excision of a retrovitally transferred oncogene," Human Gene Therapy, vol. 10, no. 10, pp. 1607-1617, 1999.

[164] N. Kobayashi, H. Noguchi, K. A. Westerman et al., "Efficient Cre/loxP site-specific recombination in a HepG2 human liver cell line," Cell Transplantation, vol. 9, no. 5, pp. 737-742, 2000.

[165] H. Duplan, J. C. Bes, M. Tafani et al., "Adrenal medullary explants as an efficient tool for pain control: adhesive biomolecular components are involved in graft function ex vivo," Experimental Neurology, vol. 163, no. 2, pp. 331-347, 2000.

[166] H. Wang and J. Sagen, "Optimization of adrenal medullary allograft conditions for pain alleviation," Journal of Neural Transplantation and Plasticity, vol. 5, no. 1, pp. 49-64, 1994.

[167] J. D. Ortega and J. Sagen, "Pharmacologic characterization of opioid peptide release from chromaffin cell transplants using a brain slice superfusion method," Experimental Brain Research, vol. 95, no. 3, pp. 381-387, 1993.

[168] A. Tjolsen, O. G. Berge, S. Hunskaar, J. H. Rosland, and K. Hole, "The formalin test: an evaluation of the method," Pain, vol. 51, no. 1, pp. 5-17, 1992.

[169] K. McCormack, P. Prather, and C. Chapleo, "Some new insights into the effects of opioids in phasic and tonic nociceptive tests," Pain, vol. 78, no. 2, pp. 79-98, 1998.

[170] H. Duplan, R. Y. Li, C. Vue et al., "Grafts of immortalized chromaffin cells bio-engineered to improve met-enkephalin 
release also reduce formalin-evoked c-fos expression in rat spinal cord," Neuroscience Letters, vol. 370, no. 1, pp. 1-6, 2004.

[171] D. Ferber, "Public health: creeping consensus on SV40 and polio vaccine," Science, vol. 298, no. 5594, pp. 725-727, 2002.

[172] J. Liu, J. Pan, S. Naik et al., "Characterization and evaluation of detoxification functions of a nontumorigenic immortalized porcine hepatocyte cell line (HepLiu)," Cell Transplantation, vol. 8, no. 3, pp. 219-232, 1999.

[173] A. Villa, E. Y. Snyder, A. Vescovi, and A. Martínez-Serrano, "Establishment and properties of a growth factor-dependent, perpetual neural stem cell line from the human CNS," Experimental Neurology, vol. 161, no. 1, pp. 67-84, 2000.

[174] F. Deimling, S. Finotto, K. Lindner et al., "Characterization of adrenal chromaffin progenitor cells in mice," Advances in Pharmacology, vol. 42, pp. 932-935, 1998.

[175] A. Schober, K. Krieglstein, and K. Unsicker, "Molecular cues for the development of adrenal chromaffin cells and their preganglionic innervation," European Journal of Clinical Investigation, Supplement, vol. 30, supplement 3, pp. 87-90, 2000.

[176] M. J. Eaton, S. Q. Wolfe, and E. Widerstrom-Noga, "Use of progenitor cells in pain management," in Stem Cell \& Regenerative Medicine, H. Cheung, Ed., pp. 94-128, Bentham Science, Oak Park, Ill, USA, 2010.

[177] M. B. Newman, I. Misiuta, A. E. Willing et al., "Tumorigenicity issues of embryonic carcinoma-derived stem cells: relevance to surgical trials using NT2 and hNT neural cells," Stem Cells and Development, vol. 14, no. 1, pp. 29-43, 2005.

[178] D. H. Park, C. V. Borlongan, D. J. Eve, and P. R. Sanberg, "The emerging field of cell and tissue engineering," Medical Science Monitor, vol. 14, no. 11, pp. RA206-RA220, 2008.

[179] E. N. Kozlova, "Strategies to repair lost sensory connections to the spinal cord," Molekuliarnaia Biologiia, vol. 42, no. 5, pp. 820-829, 2008.

[180] A. N. Raval, "Therapeutic potential of adult progenitor cells in the management of chronic myocardial ischemia," American Journal of Cardiovascular Drugs, vol. 8, no. 5, pp. 315326, 2008.

[181] M. S. Goligorsky, M. C. Kuo, D. Patschan, and M. C. Verhaar, "Review article: endothelial progenitor cells in renal disease," Nephrology, vol. 14, no. 3, pp. 291-297, 2009.

[182] C. Stamm, Y. H. Choi, B. Nasseri, and R. Hetzer, "A heart full of stem cells: the spectrum of myocardial progenitor cells in the postnatal heart," Therapeutic Advances in Cardiovascular Disease, vol. 3, no. 3, pp. 215-229, 2009.

[183] M. Jevon, A. Dorling, and P. I. Hornick, "Progenitor cells and vascular disease," Cell Proliferation, vol. 41, supplement 1, pp. 146-164, 2008.

[184] C. R. Lin, P. C. Wu, H. C. Shih et al., "Intrathecal spinal progenitor cell transplantation for the treatment of neuropathic pain," Cell Transplantation, vol. 11, no. 1, pp. 17-24, 2002.

[185] T. Terashima, H. Kojima, M. Fujimaya et al., "The fusion of bone-marrow-derived proinsulin-expressing with nerve cells underlies diabetic neuropathy," Proceedings of the National Academy of Sciences of the United States of America, vol. 102, no. 35, pp. 12525-12530, 2005.

[186] E. Akesson, M. Sandelin, N. Kanaykina, H. Aldskogius, and E. N. Kozlova, "Long-term survival, robust neuronal differentiation, and extensive migration of human forebrain stem/progenitor cells transplanted to the adult rat dorsal root ganglion cavity," Cell Transplantation, vol. 17, no. 10-11, pp. 1115-1123, 2008.
[187] P. W. Andrews, I. Damjanov, D. Simon et al., "Pluripotent embryonal carcinoma clones derived from the human teratocarcinoma cell line Tera-2. Differentiation in vivo and in vitro," Laboratory Investigation, vol. 50, no. 2, pp. 147-162, 1984.

[188] S. J. Pleasure and V. M. Y. Lee, "NTera 2 cells: a human cell line which displays characteristics expected of a human committed neuronal progenitor cell," Journal of Neuroscience Research, vol. 35, no. 6, pp. 585-602, 1993.

[189] P. W. Andrews, "Retinoic acid induces neuronal differentiation of a cloned human embryonal carcinoma cell line in vitro," Developmental Biology, vol. 103, no. 2, pp. 285-293, 1984.

[190] C. V. Borlongan, Y. Tajima, J. Q. Trojanowski, V. M. Y. Lee, and P. R. Sanberg, "Transplantation of cryopreserved human embryonal carcinoma-derived neurons (NT2N cells) promotes functional recovery in ischemic rats," Experimental Neurology, vol. 149, no. 2, pp. 310-321, 1998.

[191] W. M. W. Cheung, A. H. Chu, M. F. Leung, and N. Y. Ip, "Induction of trk receptors by retinoic acid in a human embryonal carcinoma cell line," NeuroReport, vol. 7, no. 6, pp. 1204-1208, 1996.

[192] A. Ferrari, E. Ehler, R. M. Nitsch, and J. Gotz, "Immature human NT2 cells grafted into mouse brain differentiate into neuronal and glial cell types," The FEBS Letters, vol. 486, no. 2, pp. 121-125, 2000.

[193] I. Guillemain, G. Alonoso, G. Patey et al., "Human NT2 neurons express a large variety of neurotransmission phenotypes in vitro," The Journal of Comparative Neurology, vol. 422, pp. 380-395, 2000.

[194] J. I. Satoh and Y. Kuroda, "Differential gene expression between human neurons and neuronal progenitor cells in culture: an analysis of arrayed cDNA clones in NTera2 human embryonal carcinoma cell line as a model system," Journal of Neuroscience Methods, vol. 94, no. 2, pp. 155-164, 2000.

[195] I. Guillemain, G. Fontes, A. Privat, and I. Chaudieu, "Early programmed cell death in human NT2 cell cultures during differentiation induced by all-trans-retinoic retinoic acid," Journal of Neuroscience Research, vol. 71, no. 1, pp. 38-45, 2003.

[196] E. Dmitrovsky, D. Moy, W. H. Miller, A. Li, and H. Masui, "Retinoic acid causes a decline in TGF- $\alpha$ expression, cloning efficiency, and tumorigenicity in a human embryonal cancer cell line," Oncogene Research, vol. 5, no. 3, pp. 233-239, 1990.

[197] P. Gortz, W. Fleischer, C. Rosenbaum, F. Otto, and M. Siebler, "Neuronal network properties of human teratocarcinoma cell line-derived neurons," Brain Research, vol. 1018, no. 1, pp. 18-25, 2004.

[198] F. Megiorni, B. Mora, P. Indovina, and M. C. Mazzilli, "Expression of neuronal markers during NTera2/cloneD1 differentiation by cell aggregation method," Neuroscience Letters, vol. 373, no. 2, pp. 105-109, 2005.

[199] V. M. Y. Lee and P. W. Andrews, "Differentiation of NTERA2 clonal human embryonal carcinoma cells into neurons involves the induction of all three neurofilament proteins," Journal of Neuroscience, vol. 6, no. 2, pp. 514-521, 1986.

[200] M. M. Daadi, S. Saporta, A. E. Willing, T. Zigova, M. P. McGrogan, and P. R. Sanberg, "In vitro induction and in vivo expression of bcl-2 in the hNT neurons," Brain Research Bulletin, vol. 56, no. 2, pp. 147-152, 2001.

[201] J. Q. Trojanowski, S. R. Kleppner, R. S. Hartley et al., "Transfectable and transplantable postmitotic human neurons: a potential 'platform' for gene therapy of nervous system diseases," Experimental Neurology, vol. 144, no. 1, pp. 92-97, 1997. 
[202] D. Kondziolka, L. Wechsler, S. Goldstein et al., "Transplantation of cultured human neuronal cells for patients with stroke," Neurology, vol. 55, no. 4, pp. 565-569, 2000.

[203] P. T. Nelson, D. Kondziolka, L. Wechsler et al., "Clonal human (hNT) neuron grafts for stroke therapy: neuropathology in a patient 27 months after implantation," American Journal of Pathology, vol. 160, no. 4, pp. 1201-1206, 2002.

[204] C. C. Meltzer, D. Kondziolka, V. L. Villemagne et al., "Serial ${ }^{[18 \mathrm{~F}]}$ fluorodeoxyglucose positron emission tomography after human neuronal implantation for stroke," Neurosurgery, vol. 49, no. 3, pp. 586-592, 2001.

[205] D. Usvald, P. Vodicka, J. Hlucilova et al., "Analysis of dosing regimen and reproducibility of intraspinal grafting of human spinal stem cells in immunosuppressed minipigs," Cell Transplantation, vol. 19, no. 9, pp. 1103-1122, 2010.

[206] A. Yoshioka, M. Yudkoff, and D. Pleasure, "Expression of glutamic acid decarboxylase during human neuronal differentiation: studies using the NTera-2 culture system," Brain Research, vol. 767, no. 2, pp. 333-339, 1997.

[207] G. Podrygajlo, M. A. Tegenge, A. Gierse et al., "Cellular phenotypes of human model neurons (NT2) after differentiation in aggregate culture," Cell and Tissue Research, vol. 336, no. 3, pp. 439-452, 2009.

[208] S. Saporta, A. E. Willing, L. O. Colina et al., "In vitro and in vivo characterization of hNT neuron neurotransmitter phenotypes," Brain Research Bulletin, vol. 53, no. 3, pp. 263 268,2000

[209] M. Bosch, J. R. Pineda, C. Sunol et al., "Induction of GABAergic phenotype in a neural stem cell line for transplantation in an excitotoxic model of Huntington's disease," Experimental Neurology, vol. 190, no. 1, pp. 42-58, 2004.

[210] Q. L. Cao, R. M. Howard, J. B. Dennison, and S. R. Whittemore, "Differentiation of engrafted neuronal-restricted precursor cells is inhibited in the traumatically injured spinal cord," Experimental Neurology, vol. 177, no. 2, pp. 349-359, 2002.

[211] P. J. Cejas, M. Martinez, S. Karmally et al., "Lumbar transplant of neurons genetically modified to secrete brainderived neurotrophic factor attenuates allodynia and hyperalgesia after sciatic nerve constriction," Pain, vol. 86, no. 1-2, pp. 195-210, 2000.

[212] M. J. Eaton, S. Q. Wolfe, M. Martinez et al., "Subarachnoid transplant of a human neuronal cell line attenuates chronic allodynia and hyperalgesia after excitotoxic SCI in the rat," Journal of Pain, vol. 8, no. 1, pp. 33-50, 2007.

[213] M. J. Eaton, D. D. Pearse, J. S. McBroom, and Y. A. Berrocal, "The combination of human neuronal serotonergic cell implants and environmental enrichment after contusive SCI improves motor recovery over each individual strategy," Behavioural Brain Research, vol. 194, no. 2, pp. 236-241, 2008.

[214] J. Sagen, "Cellular therapies for spinal cord injury: what will the FDA need to approve moving from the laboratory to the human?" Journal of Rehabilitation Research and Development, vol. 40, no. 4, supplement 1, pp. 71-79, 2003.

[215] R. P. Yezierski, S. Liu, G. L. Ruenes, K. J. Kajander, and K. L. Brewer, "Excitotoxic spinal cord injury: behavioral and morphological characteristics of a central pain model," Pain, vol. 75, no. 1, pp. 141-155, 1998.

[216] R. P. Yezierski and S. H. Park, "The mechanosensitivity of spinal sensory neurons following intraspinal injections of quisqualic acid in the rat," Neuroscience Letters, vol. 157, no. 1, pp. 115-119, 1993.
[217] S. Liu, G. L. Ruenes, and R. P. Yezierski, "NMDA and non-NMDA receptor antagonists protect against excitotoxic injury in the rat spinal cord," Brain Research, vol. 756, no. 1-2, pp. 160-167, 1997.

[218] V. Dietz and A. Curt, "Neurological aspects of spinal-cord repair: promises and challenges," The Lancet Neurology, vol. 5, no. 8, pp. 688-694, 2006.

[219] K. L. Brewer and R. P. Yezierski, "Effects of adrenal medullary transplants on pain-related behaviors following excitotoxic spinal cord injury," Brain Research, vol. 798, no. 1-2, pp. 8392, 1998.

[220] C. O. Stiller, J. G. Cui, W. T. O’Connor et al., “GABA-ergic mechanisms may be involved in the spinal cord stimulation induced reversion of allodynia: animal studies with microdialysis," American Pain Society Abstracts, vol. 95, article 801, 1995.

[221] C. Qin, J. Q. Du, J. S. Tang, and R. D. Foreman, "Bradykinin is involved in the mediation of cardiac nociception during ischemia through upper thoracic spinal neurons," Current Neurovascular Research, vol. 6, no. 2, pp. 89-94, 2009.

[222] J. G. Meisner, A. D. Marsh, and D. R. Marsh, "Loss of GABAergic interneurons in laminae I-III of the spinal cord dorsal horn contributes to reduced GABAergic tone and neuropathic pain after spinal cord injury," Journal of Neurotrauma, vol. 27, no. 4, pp. 729-737, 2010.

[223] F. I. Sutherland, B. Anne Bannatyne, R. Kerr, J. S. Riddell, and D. J. Maxwell, "Inhibitory amino acid transmitters associated with axons in presynaptic apposition to cutaneous primary afferent axons in the cat spinal cord," The Journal of Comparative Neurology, vol. 452, no. 2, pp. 154-162, 2002.

[224] S. M. Wojcik, S. Katsurabayashi, I. Guillemin et al., "A shared vesicular carrier allows synaptic corelease of GABA and glycine," Neuron, vol. 50, no. 4, pp. 575-587, 2006.

[225] S. Q. Wolfe, M. Garg, N. M. A. Cumberbatch et al., "Optimizing the transplant dose of a human neuronal cell line graft to treat SCI pain in the rat," Neuroscience Letters, vol. 414, no. 2, pp. 121-125, 2007.

[226] M. J. Eaton and S. Q. Wolfe, "Clinical feasibility for cell therapy using human neuronal cell line to treat neuropathic behavioral hypersensitivity following spinal cord injury in rats," Journal of Rehabilitation Research and Development, vol. 46, no. 1, pp. 145-166, 2009.

[227] M. J. Eaton and Y. Berrocal, "Potential for cell-transplant therapy with human neuronal precursors to treat neuropathic pain in models of PNS and CNS injury: comparison of hNT2.17 and hNT2.19 cell lines," Pain Research Treatment. In press.

[228] L. Vaysse, J. C. Sol, Y. Lazorthes, M. Courtade-Saidi, M. J. Eaton, and S. Jozan, "GABAergic pathway in a rat model of chronic neuropathic pain: modulation after intrathecal transplantation of a human neuronal cell line," Neuroscience Research, vol. 69, no. 2, pp. 111-120, 2011.

[229] M. J. Eaton, J. A. Plunkett, M. A. Martinez, S. Karmally, and K. Montanez, "Changes in GAD and GABA immunoreactivity in the spinal dorsal horn after peripheral nerve injury and promotion of recovery by lumbar transplant of immortalized serotonergic precursors," Journal of Chemical Neuroanatomy, vol. 16, no. 1, pp. 57-72, 1998.

[230] N. A. Calcutt, "Potential mechanisms of neuropathic pain in diabetes," International Review of Neurobiology, vol. 50, pp. 205-228, 2002.

[231] T. Z. Fischer, A. M. Tan, and S. G. Waxman, "Thalamic neuron hyperexcitability and enlarged receptive fields in the 
STZ model of diabetic pain," Brain Research, vol. 1268, no. C, pp. 154-161, 2009.

[232] T. Z. Fischer and S. G. Waxman, "Neuropathic pain in diabetes-evidence for a central mechanism," Nature Reviews Neurology, vol. 6, no. 8, pp. 462-466, 2010.

[233] S. Shapiro, "Neurotransmission by neurons that use serotonin, noradrenaline, glutamate, glycine, and $\gamma$-aminobutyric acid in the normal and injured spinal cord," Neurosurgery, vol. 40, no. 1, pp. 168-177, 1997.

[234] B. C. Hains, A. W. Everhart, S. D. Fullwood, and C. E. Hulsebosch, "Changes in serotonin, serotonin transporter expression and serotonin denervation supersensitivity: involvement in chronic central pain after spinal hemisection in the rat," Experimental Neurology, vol. 175, no. 2, pp. 347-362, 2002.

[235] B. Zhang, M. E. Goldberger, and M. Murray, "Proliferation of SP- and 5HT-containing terminals in lamina II of rat spinal cord following dorsal rhizotomy: quantitative EMimmunocytochemial studies," Experimental Neurology, vol. 123, no. 1, pp. 51-63, 1993.

[236] B. C. Hains, W. D. Willis, and C. E. Hulsebosch, "Serotonin receptors 5-HT1A and 5-HT3 reduce hyperexcitability of dorsal horn neurons after chronic spinal cord hemisection injury in rat," Experimental Brain Research, vol. 149, no. 2, pp. 174-186, 2003.

[237] Y. Saruhashi, W. Young, and R. Perkins, "The recovery of 5HT immunoreactivity in lumbosacral spinal cord and locomotor function after thoracic hemisection," Experimental Neurology, vol. 139, no. 2, pp. 203-213, 1996.

[238] M. G. Ribotta, J. Provencher, D. Feraboli-Lohnherr, S. Rossignol, A. Privát, and D. Orsal, "Activation of locomotion in adult chronic spinal rats is achieved by transplantation of embryonic raphe cells reinnervating a precise lumbar level," Journal of Neuroscience, vol. 20, no. 13, pp. 5144-5152, 2000.

[239] D. Feraboli-Lohnherr, D. Orsal, A. Yakovleff, M. G. Ribotta, and A. Privat, "Recovery of locomotor activity in the adult chronic spinal rat after sublesional transplantation of embryonic nervous cells: specific role of serotonergic neurons," Experimental Brain Research, vol. 113, no. 3, pp. 443454, 1997.

[240] L. M. Ramer, E. Au, M. W. Richter, J. Liu, W. Tetzlaff, and A. J. Roskams, "Peripheral olfactory ensheathing cells reduce scar and cavity formation and promote regeneration after spinal cord injury," The Journal of Comparative Neurology, vol. 473, no. 1, pp. 1-15, 2004.

[241] M. J. Eaton, E. Widerström-Noga, and S. Q. Wolfe, "Subarachnoid transplant of a human neuronal serotonergic cell line attenuates chronic allodynia and hyperalgesia without affecting motor dysfunction after severe contusive spinal cord injury," Neurology Research International, vol. 2011, Article ID 891605, 24 pages, 2011.

[242] P. A. Walker, M. T. Harting, S. K. Shah et al., "Progenitor cell therapy for the treatment of central nervous system injury: a review of the state of current clinical trials," Stem Cells International, vol. 2010, Article ID 369578, 8 pages, 2010.

[243] J. Hernándeza, A. Torres-Espína, and X. Navarro, "Adult stem cell transplants for spinal cord injury repair: current state in preclinical research," Current Stem Cell Research and Therapy, vol. 6, no. 3, pp. 273-287, 2011.

[244] C. V. Borlongan, C. McWhirter, C. Fultz-Carver et al., "The case for an ethics research consortium for emerging technologies: public perception of stem cell research and development," Technology and Innovation, vol. 12, pp. 21-28, 2010.

[245] B. C. Hains, K. M. Chastain, A. W. Everhart, D. J. McAdoo, and C. E. Hulsebosch, "Transplants of adrenal medullary chromaffin cells reduce forelimb and hindlimb allodynia in a rodent model of chronic central pain after spinal cord hemisection injury," Experimental Neurology, vol. 164, no. 2, pp. 426-437, 2000.

[246] M. Guenot, J. W. Lee, F. Nasirinezhad, and J. Sagen, "Deafferentation pain resulting from cervical posterior rhizotomy is alleviated by chromaffin cell transplants into the rat spinal subarachnoid space," Neurosurgery, vol. 60, no. 5, pp. 919925, 2007.

[247] M. D. Lindner, J. M. Francis, P. E. McDermott et al., "Numerous adrenal chromaffin cell preparations fail to produce analgesic effects in the formalin test or in tests of acute pain even with nicotine stimulation," Pain, vol. 88, no. 2, pp. 177-188, 2000.

[248] X. T. Wang, J. R. Unnerstall, T. Ibuki, H. Wang, and G. D. Pappas, "Comparison of tyrosine hydroxylase and preproenkephalin expression in rat adrenal medullary explants in vitro and transplanted into subarachnoid space," Experimental Neurology, vol. 161, no. 1, pp. 346-360, 2000.

[249] U. Herzberg, A. Hama, and J. Sagen, "Spinal subarachnoid adrenal medullary transplants reduce hind paw swelling and peripheral nerve transport following formalin injection in rats," Brain Research, vol. 1198, pp. 85-92, 2008.

[250] J. D. Ortega, J. Sagen, and G. D. Pappas, "Survival and integration of bovine chromaffin cells transplanted into rat central nervous system without exogenous trophic factors," The Journal of Comparative Neurology, vol. 323, no. 1, pp. 1324, 1992.

[251] K. A. Czech, J. W. Ryan, J. Sagen, and G. D. Pappas, "The influence of xenotransplant immunogenicity and immunosuppression on host MHC expression in the rat CNS," Experimental Neurology, vol. 147, no. 1, pp. 66-83, 1997.

[252] I. Decosterd, E. Buchser, N. Gilliard, J. Saydoff, A. D. Zurn, and P. Aebischer, "Intrathecal implants of bovine chromaffin cells alleviate mechanical allodynia in a rat model of neuropathic pain," Pain, vol. 76, no. 1-2, pp. 159-166, 1998.

[253] J. C. Sol, R. Y. Li, B. Sallerin et al., "Intrathecal grafting of porcine chromaffin cells reduces formalin-evoked c-Fos expression in the rat spinal cord," Cell Transplantation, vol. 14, no. 6, pp. 353-365, 2005.

[254] Y. Lu, R. Jing, D. C. Yeomans, and G. D. Pappas, "Porcine chromaffin cells, culture, and transplant for antinociceptive effects in rodents and primates," Neurological Research, vol. 26, no. 7, pp. 707-712, 2004.

[255] W. Yu, J. X. Haoa, X. J. Xu et al., "Immunoisolating encapsulation of intrathecally implanted bovine chromaffin cells prolongs their survival and produces anti-allodynic effect in spinally injured rats," European Journal of Pain, vol. 2, no. 2, pp. 143-151, 1998.

[256] M. D. Lindner, J. M. Francis, M. A. Plone et al., "The analgesic potential of intraventricular polymer-encapsulated adrenal chromaffin cells in a rodent model of chronic neuropathic pain," Experimental and Clinical Psychopharmacology, vol. 8, no. 4, pp. 524-538, 2000.

[257] T. Moustafa, S. Girod, F. Tortosa et al., "Viability and functionality of bovine chromaffin cells encapsulated into alginate-PLL microcapsules with a liquefied inner core," Cell Transplantation, vol. 15, no. 2, pp. 121-133, 2006.

[258] S. R. Winn and D. F. Emerich, "Managing chronic pain with encapsulated cell implants releasing catecholamines and endogenous opiods," Frontiers in Bioscience, vol. 10, no. 1, pp. 367-378, 2005.

[259] Y. M. Elcin, A. E. Elcin, and G. D. Pappas, "Functional and morphological characteristics of bovine adrenal chromaffin cells on macroporous poly(D,L-lactide-co-glycolide) scaffolds," Tissue Engineering, vol. 9, no. 5, pp. 1047-1056, 2003. 
[260] J. C. Sol, S. Larrue, R. Y. Li et al., "Intrathecal grafting of porcine chromaffin cells in the rat reduce nociception in a tonic pain model," Experimental Neurology, vol. 175, article 433, 2002.

[261] J. C. Sol, B. Sallerin, S. Larrue et al., "Intrathecal xenogeneic chromaffin cell grafts reduce nociceptive behavior in a rodent tonic pain model," Experimental Neurology, vol. 186, no. 2, pp. 198-211, 2004.

[262] Y. M. Kim, K. H. Kwak, J. O. Lim, and W. Y. Baek, "Reduction of allodynia by intrathecal transplantation of microencapsulated porcine chromaffin cells," Artificial Organs, vol. 33, no. 3, pp. 240-249, 2009.

[263] J. T. Hansen, M. F. D. Notter, S. H. Okawara, and D. M. Gash, "Organization, fine structure, and viability of the human adrenal medulla: considerations for neural transplantation," Annals of Neurology, vol. 24, no. 5, pp. 599-609, 1988.

[264] H. Zhou, J. Aziza, J. C. Sol et al., "Cell therapy of pain: characterization of human fetal chromaffin cells at early adrenal medulla development," Experimental Neurology, vol. 198, no. 2, pp. 370-381, 2006.

[265] W. Yu, J. X. Hao, X. J. Xu et al., "Long-term alleviation of allodynia-like behaviors by intrathecal implantation of bovine chromaffin cells in rats with spinal cord injury," Pain, vol. 74, no. 2-3, pp. 115-122, 1998.

[266] J. Tkaczuk, J. C. Bes, H. de Bouet du Portal et al., "Intrathecal allograft of chromaffin cells for intractable pain treatment: a model for understanding CNS tolerance mechanisms in humans," Transplantation Proceedings, vol. 29, no. 5, pp. 2356-2357, 1997.

[267] J. M. Joseph, M. B. Goddard, J. Mills et al., "Transplantation of encapsulated bovine chromaffin cells in the sheep subarachnoid space: a preclinical study for the treatment of cancer pain," Cell Transplantation, vol. 3, no. 5, pp. 355-364, 1994.

[268] H. Wang and J. Sagen, "Attenuation of pain-related hyperventilation in adjuvant arthritic rats with adrenal medullary transplants in the spinal subarachnoid space," Pain, vol. 63, no. 3, pp. 313-320, 1995.

[269] M. D. Lindner, B. R. Frydel, J. M. Francis, and C. K. Cain, "Analgesic effects of adrenal chromaffin allografts: contingent on special procedures or due to experimenter bias?" Journal of Pain, vol. 4, no. 2, pp. 64-73, 2003.

[270] M. D. Lindner, "Clinical attrition due to biased preclinical assessments of potential efficacy," Pharmacology and Therapeutics, vol. 115, no. 1, pp. 148-175, 2007.

[271] M. D. Lindner, J. M. Francis, and J. A. Saydoff, "Erratum: intrathecal polymer-encapsulated bovine adrenal chromaffin cells fail to produce analgesic effects in the hotplate and formalin test (Experimental Neurology (2000) 165:2 (370383))," Experimental Neurology, vol. 170, no. 1, p. 225, 2001.

[272] S. Wu, C. Ma, G. Li, M. Mai, and Y. Wu, "Intrathecal implantation of microencapsulated PC12 cells reduces cold allodynia in a rat model of neuropathic pain," Artificial Organs, vol. 35, no. 3, pp. 294-300, 2011.

[273] H. H. Wu, S. C. McLoon, and G. L. Wilcox, "Antinociception following implantation of AtT-20 and genetically modified AtT-20/hENK cells in rat spinal cord," Journal of Neural Transplantation and Plasticity, vol. 4, no. 1, pp. 15-26, 1993.

[274] M. Hino, T. Ogata, T. Morino, H. Horiuchi, and H. Yamamoto, "Intrathecal transplantation of autologous macrophages genetically modified to secrete proenkephalin ameliorated hyperalgesia and allodynia following peripheral nerve injury in rats," Neuroscience Research, vol. 64, no. 1, pp. 56-62, 2009.
[275] L. A. White and S. R. Whittemore, "Immortalization of raphe neurons: an approach to neuronal function in vitro and in vivo," Journal of Chemical Neuroanatomy, vol. 5, no. 4, pp. 327-330, 1992.

[276] L. A. White, R. W. Keane, and S. R. Whittemore, "Differentiation of an immortalized CNS neuronal cell line decreases their susceptibility to cytotoxic T cell lysis in vitro," Journal of Neuroimmunology, vol. 49, no. 1-2, pp. 135-143, 1994.

[277] S. R. Whittemore, L. A. White, L. S. Shihabuddin, and M. J. Eaton, "Phenotypic diversity in neuronal cell lines derived from raphe nucleus by retroviral transduction," Methods, vol. 7, no. 3, pp. 285-296, 1995.

[278] H. K. Raymon, S. Thode, J. Zhou et al., "Immortalized human dorsal root ganglion cells differentiate into neurons with nociceptive properties," Journal of Neuroscience, vol. 19, no. 13, pp. 5420-5428, 1999.

[279] M. J. Eaton, L. Vaysse, J. P. Herman et al., "Creation of immortalized chromaffin cell lines for clinical applications," IRPCA Advances and Research Updates, vol. 9, no. 1, pp. 1326, 2007.

[280] W. R. Galpern, L. H. Burns, T. W. Deacon, J. Dinsmore, and O. Isacson, "Xenotransplantation of porcine fetal ventral mesencephalon in a rat model of Parkinson's disease: functional recovery and graft morphology," Experimental Neurology, vol. 140, no. 1, pp. 1-13, 1996.

[281] J. C. Bes and J. Sagen, "Dissociated human embryonic and fetal adrenal glands in neural stem cell culture system: open fate for neuronal, nonneuronal, and chromaffin lineages?" Annals of the New York Academy of Sciences, vol. 971, pp. 563$572,2002$.

[282] C. E. Goodfellow, S. E. Graham, M. Dragunow, and M. Glass, "Characterization of NTera2/D1 cells as a model system for the investigation of cannabinoid function in human neurons and astrocytes," Journal of Neuroscience Research, vol. 89, no. 10, pp. 1685-1697, 2011.

[283] J. Eaton and Y. Berrocal, "Potential for cell-transplant therapy with human neuronal precursors to treat neuropathic pain in models of PNS and CNS injury: comparison of hNT2.17 and hNT2.19 cell lines," Pain Research Treatment. In press.

[284] S. C. Quintero Wolfe, N. Cumberbatch, I. Menendez, M. Martinez, and M. Eaton, "Intrathecal transplantation of a human neuronal cell line for the treatment of neuropathic pain in a spinal cord injury model," Clinical Neurosurgery, vol. 54, pp. 220-225, 2007.

[285] M. J. Eaton, "Development of human cell therapy for functional recovery following SCI," The Journal of Spinal Cord Medicine, vol. 27, article 155, 2004. 


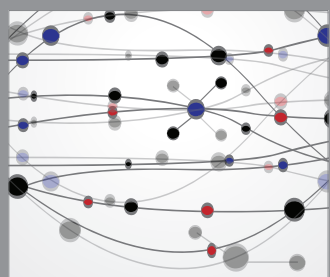

The Scientific World Journal
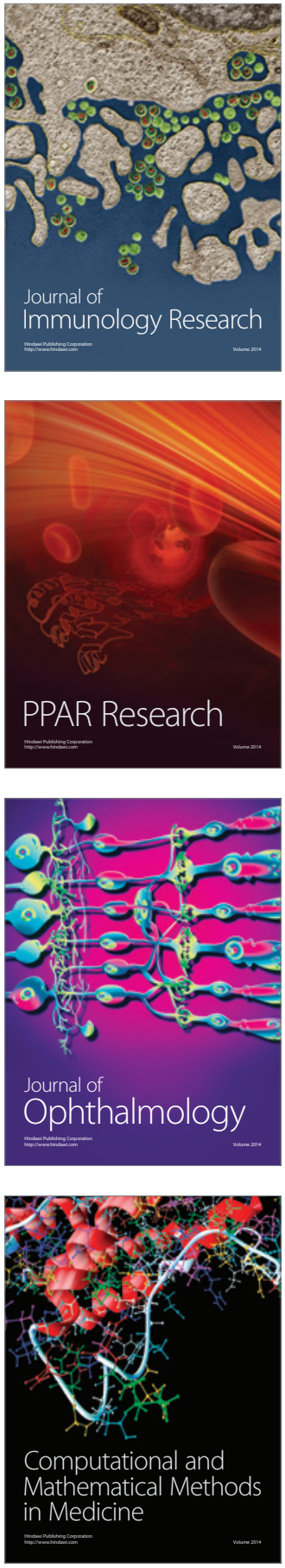

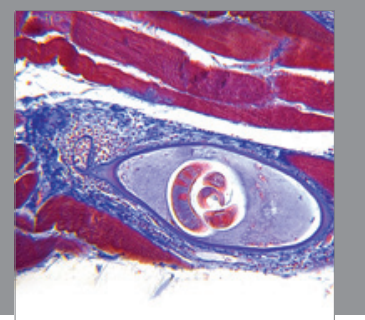

Gastroenterology

Research and Practice
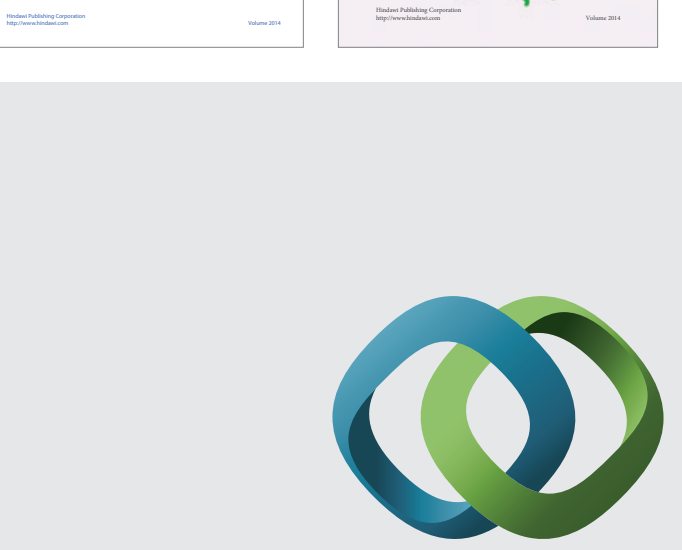

\section{Hindawi}

Submit your manuscripts at

http://www.hindawi.com
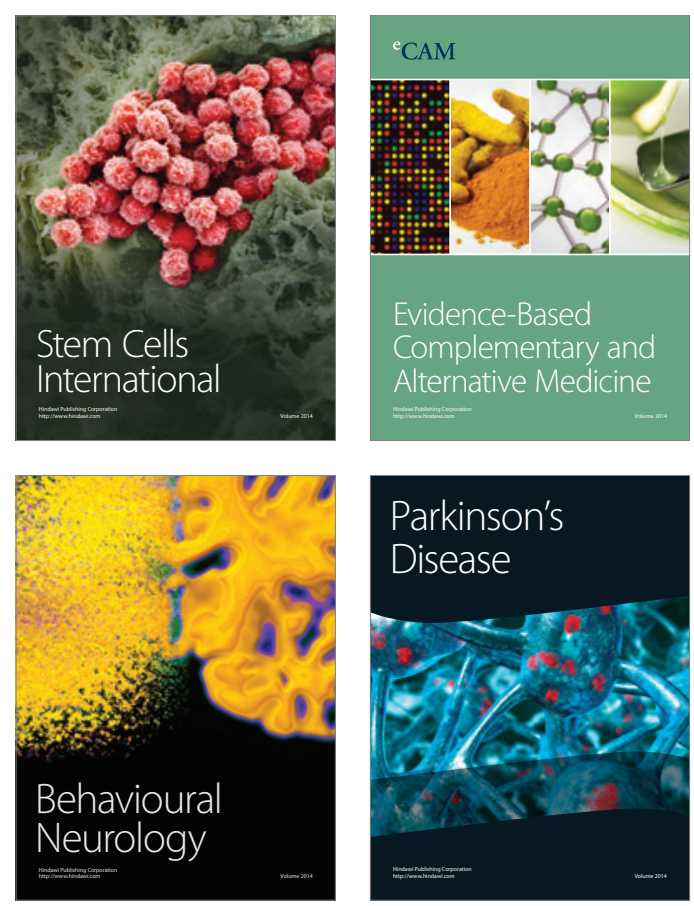

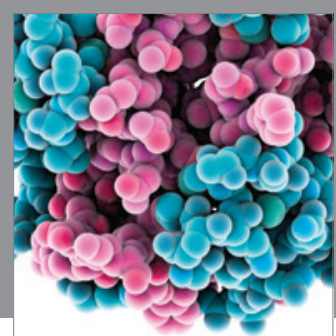

Journal of
Diabetes Research

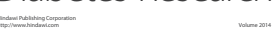

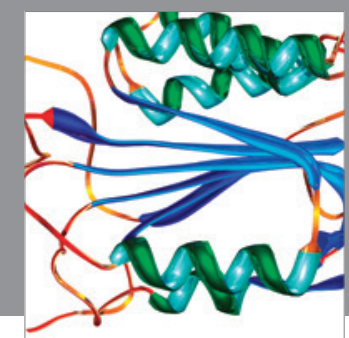

Disease Markers
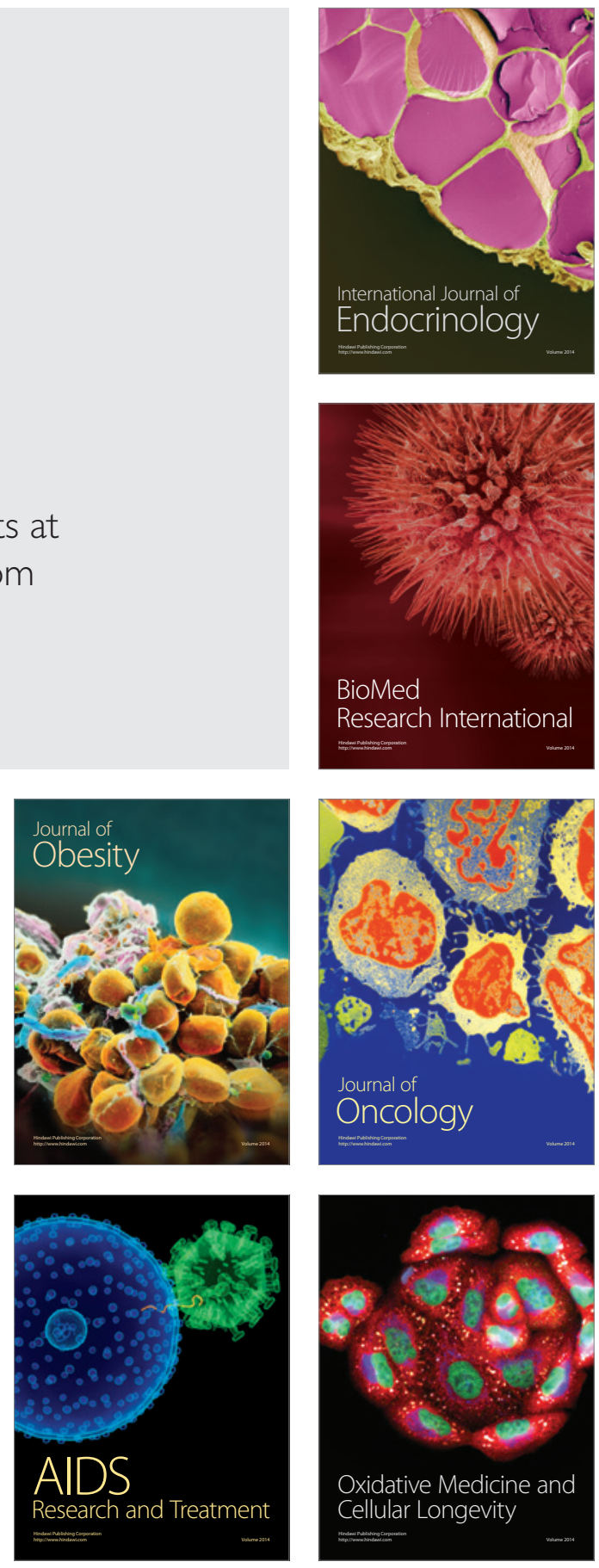